\title{
Are the Near-Antarctic Easterly Winds Weakening in Response to Enhancement of the Southern Annular Mode?
}

\author{
Julia E. HAZEL AND ANDREW L. STEWART \\ Department of Atmospheric and Oceanic Sciences, University of California, Los Angeles, \\ Los Angeles, California
}

(Manuscript received 22 June 2018, in final form 11 January 2019)

\begin{abstract}
Previous studies have highlighted the sensitivity of the Southern Ocean circulation to the strengthening, poleward-shifting westerlies, associated with the increasingly positive southern annular mode (SAM). The impacts of the SAM have been hypothesized to weaken momentum input to the ocean from the easterly winds around the Antarctic margins. Using ERA-Interim data, the authors show that the circumpolaraveraged easterly wind stress has not weakened over the past 3-4 decades, and, if anything, has slightly strengthened by around $7 \%$. However, there has been a substantial increase in the seasonality of the easterlies, with a weakening of the easterly winds during austral summer and a strengthening during winter. A similar trend in the seasonality of the easterlies is found in three other reanalysis products that compare favorably with Antarctic meteorological observations. The authors associate the strengthening of the easterly winds during winter with an increase in the pressure gradient between the coast and the pole. Although the trend in the overall easterly wind strength is small, the change in the seasonal cycle may be expected to reduce the shoreward Ekman transport of summer surface waters and also to admit more warm Circumpolar Deep Water to the continental shelf in summer. Changes in the seasonal cycle of the near-coastal winds may also project onto seasonal formation and export of sea ice, fluctuations in the strengths of the Weddell and Ross Gyres, and seasonal export of Antarctic Bottom Water from the continental shelf.
\end{abstract}

\section{Introduction}

The large-scale circulation in the Southern Ocean is dependent upon the wind stress imparted by the atmosphere (Munk and Palmén 1951). The strong westerly winds of the Southern Hemisphere ( $\mathrm{SH})$ midlatitudes drive the Antarctic Circumpolar Current (ACC; Gnanadesikan and Hallberg 2000), a strong, unbounded flow that connects the major ocean basins and permits a global overturning circulation (Rintoul 2010). Farther south, easterly winds force the ocean around the Antarctic coast. Though the easterlies force a much narrower band of the ocean surface than the westerlies, they remain critical to the exchange of water masses across the Antarctic shelf break. In particular, they sustain the Antarctic Slope Front (ASF), across which newly formed dense water is exported from the continental shelf (Gill 1973; Jacobs 1991). Figures 1a and 1b show the multidecadalmean surface wind stress over the Southern Ocean, and Fig. 1c contrasts the midlatitude westerlies with the band

Corresponding author: Julia E. Hazel, jhazel@atmos.ucla.edu of easterlies around the Antarctic margins (see Table 1 for definitions of labeled reference points). Though for convenience we refer to the latter as "easterly winds," it is more accurate to describe their direction as "anticyclonic" because they tend to be oriented parallel to the coastline rather than strictly easterly. The easterlies are supported by a combination of geostrophic flow associated with the pressure gradient between the highaltitude continental interior and the low pressure coastal trough and Coriolis deflection of offshore katabatic winds toward the west (Parish and Bromwich 1997). As a result, the shape of the continent obscures this band in a zonal average, so in Figs. 1d and 1e we plot the more dynamically relevant, alongshore component of the wind stress (see section 2 for details). Here the mean alongshore wind stress is easterly except at the Antarctic Peninsula, which protrudes into the ACC.

The most prominent change in the near-Antarctic climate has been the enhancement of the westerly winds over the past few decades (Thompson and Solomon 2002). This shift coincides with the trend toward the high-index polarity of the southern annular mode 

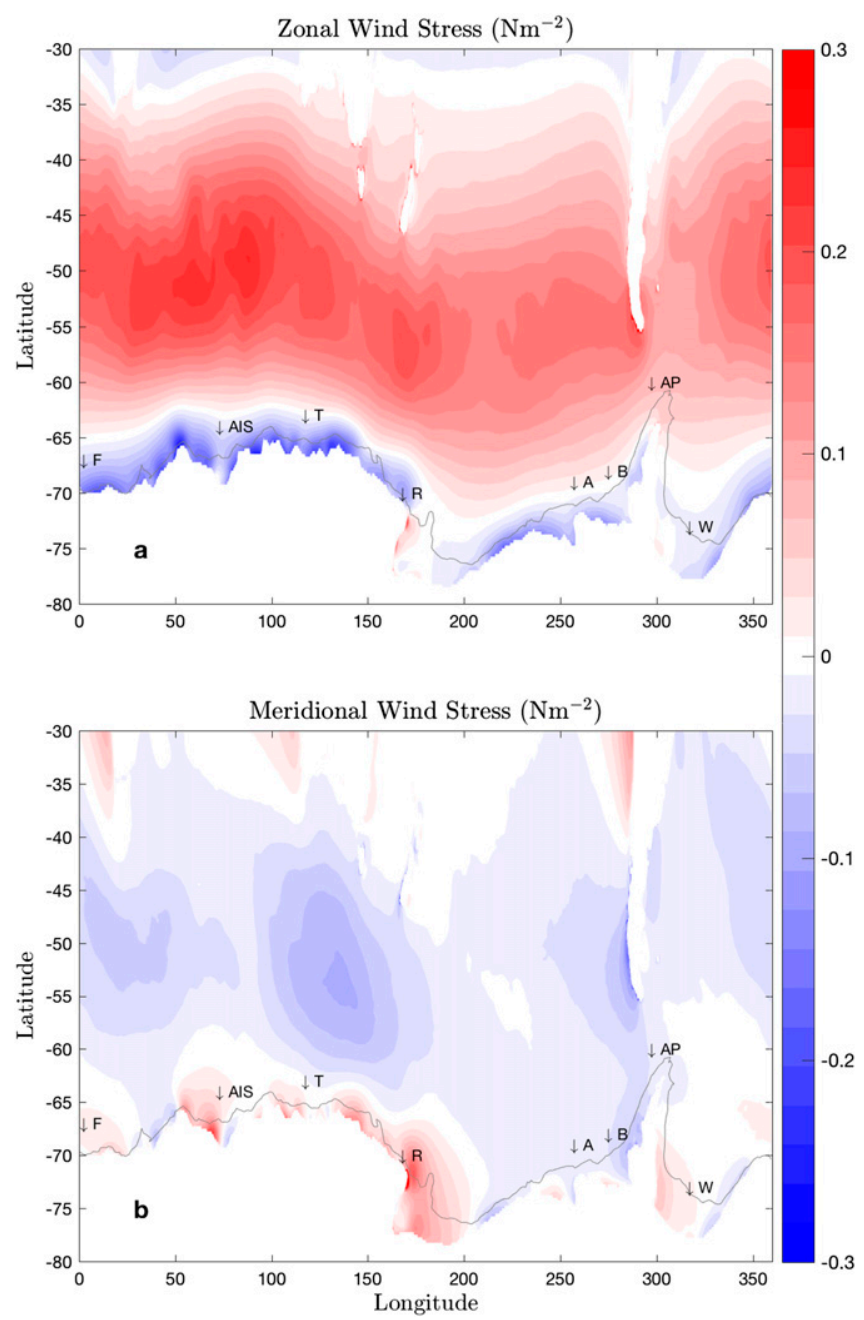

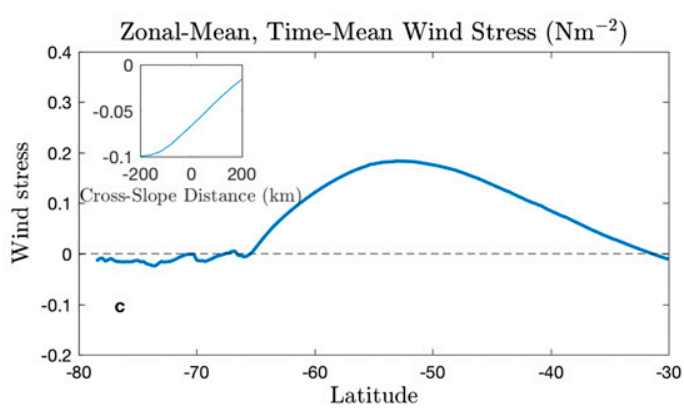

0.1
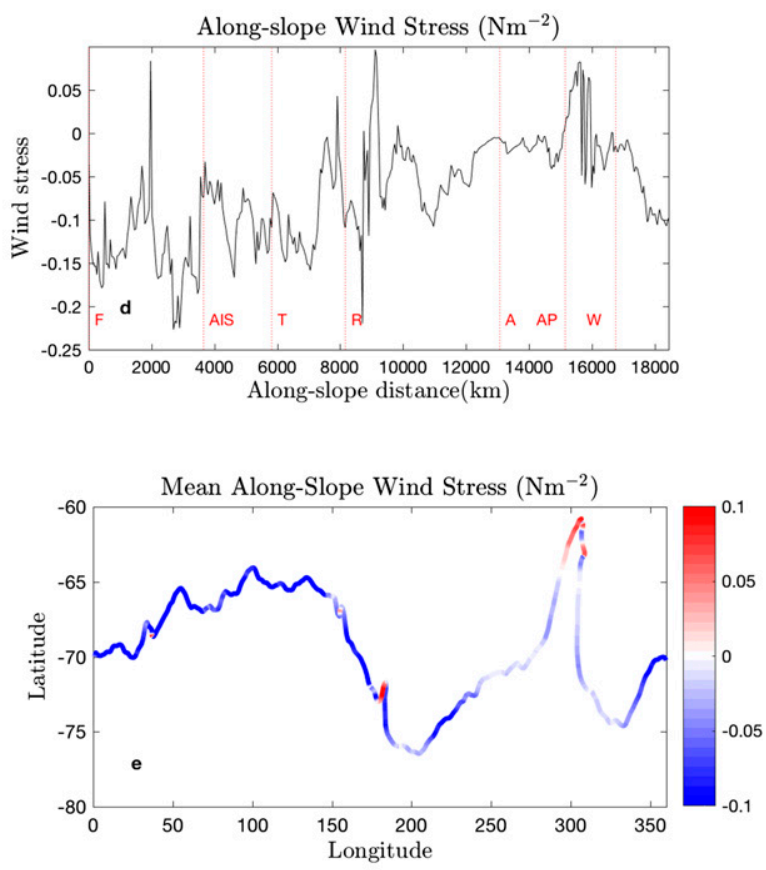

FIG. 1. Multidecadal mean surface wind forcing around the Antarctic margins from 1979-2014 ERA-Interim data (Dee et al. 2011). (a) Mean zonal wind stress $\left(\mathrm{N} \mathrm{m}^{-2}\right)$, (b) mean meridional wind stress $\left(\mathrm{N} \mathrm{m}^{-2}\right)$, (c) zonal- and time-mean wind stress $\left(\mathrm{N} \mathrm{m}^{-2}\right),(\mathrm{d})$ mean along-slope wind stress $\left(\mathrm{N} \mathrm{m}^{-2}\right)$ as a function of along-slope distance, and (e) mean along-slope wind stress $\left(\mathrm{N} \mathrm{m}^{-2}\right)$ projected onto the circum-Antarctic 1000-m depth contour. The inset in (c) shows an alternative wind stress profile obtained by averaging in time and along the coast. Labels in (a) and (b) indicate reference points to aid interpretation of (d). See Table 1 for further details.

(SAM; Marshall 2003; Turner et al. 2005). When the SAM is in this positive phase, a high pressure signal exists over the $\mathrm{SH}$ midlatitudes with low pressure toward the higher latitudes. A positive SAM induces a stronger, poleward-shifted westerly wind belt (Thompson and Solomon 2002). The trend in the SAM has spurred more research and interest into the changes in the strength of the westerly winds and their impact on the ocean circulation (Meredith and Hogg 2006; Swart and Fyfe 2012; Hogg et al. 2015; Bracegirdle 2013). This trend is likely a response to both greenhouse gas (GHG) and ozone emissions (Wang et al. 2014) and is expected to result in long-term reductions in $\mathrm{CO}_{2}$ and heat uptake in the Southern Ocean (Sallée et al. 2010; Lenton and Matear 2007). The first EOF of the SAM projects onto the Antarctic coastline, so enhancement of the SAM may be expected to decrease the strength of the near-Antarctic easterlies (e.g., Langlais et al. 2015).

The easterly winds play a central role in modulating exchanges across the Antarctic shelf break. The oceanic

TABLE 1. Definitions of labeled reference points along the Antarctic coast

\begin{tabular}{cl}
\hline \hline Acronym & \multicolumn{1}{c}{ Location } \\
\hline F & Filchner Ice Shelf \\
AIS & Amery Ice Shelf \\
T & Totten Glacier \\
R & Ross Sea \\
A & Amundsen Sea \\
AP & Antarctic Peninsula \\
W & Weddell Sea \\
\hline
\end{tabular}


transport of heat toward Antarctica's marine-terminating glaciers and ice shelves is supplied by warm, salty Circumpolar Deep Water (CDW; Jenkins et al. 2016; Heywood et al. 2016). Spence et al. (2014) used a $1 / 4^{\circ}$ ocean-sea ice model to show that a reduction of Ekman pumping occurs because of weakened easterly winds and strengthened, southward-shifting westerly winds. This leads to CDW intrusion and rapid heating of ice shelf waters. However, this mechanism may be less efficient where the Antarctic Slope Current (ASC) experiences strong tidal forcing (Flexas et al. 2015; Stewart et al. 2018). A weakening of the easterlies in the western Ross and Weddell Seas could also be expected to enhance shoreward CDW transport by raising the pycnocline at the shelf break (Thompson et al. 2014; Stewart and Thompson 2015a).

Trends in the near-Antarctic easterly wind stress have impacts beyond their influence on the Antarctic coast. For example, (i) a reduction or a shift in the easterly wind stress around the continent may directly modify the rate of Antarctic Bottom Water (AABW) export across the continental slope (Stewart and Thompson 2012, 2013). Globally, AABW has been warming, freshening, and thinning over the past few decades (Purkey and Johnson 2010; Jullion et al. 2013; Meijers et al. 2016), though the cause remains unclear. The export of AABW from the Weddell Gyre is also mediated by the changes in the winds around the Antarctic margins (Jullion et al. 2010). (ii) Changes in the easterly winds have the potential to alter the strength of the southern branch of the ACC via the "free mode" mechanism, in which the depth-averaged velocity of the ACC is accelerated by the near-Antarctic wind stress along a circum-Antarctic $f / h$ contour (Hughes et al. 1999; Zika et al. 2013). (iii) The coastal winds play a leading role in ice formation and export (Holland and Kwok 2012; Kwok et al. 2017; Haumann et al. 2016).

In addition to changes associated with the enhancement of the westerly wind belt, the easterlies are influenced by changes in the Antarctic katabatic winds. The pole-tocoast downslope pressure gradient drives these winds down the sloping continent toward the coast, where they turn westward under the influence of the Coriolis force (Parish and Waight 1987). A large-scale low atmospheric pressure system over the Antarctic coast enhances katabatic winds (Parish et al. 1993; Parish and Bromwich 2007), which may in turn be expected to enhance alongshore winds.

In this article, we quantify the trends in the easterly surface forcing around Antarctica over the past several decades to examine their response to the enhancement of the SAM. In section 2, we describe our data sources and methods used to calculate the wind stress trends, the trends in the SAM, and the strength of the katabatic winds. In section 3, we show that the air-sea momentum exchange in the easterly wind band has remained approximately unchanged, but that there has been a substantial change in the seasonal cycle of the alongshore wind forcing. We further perform a comparison of these results against other observationally validated reanalysis products. In section 4, we summarize our findings and discuss the potential implications of the diagnosed trends, and in section 5, we provide concluding remarks and discuss the outlook for further research.

\section{Data and methods}

\section{a. Data}

We use the wind stress reported by reanalysis datasets for our calculations because insufficient direct observations are available to calculate the trends. Our primary dataset is ERA-Interim (Dee et al. 2011), which we use to calculate the trend in the easterly wind stress from the monthly mean surface fluxes. We compare ERA-Interim with the Japanese 55-year Reanalysis (JRA-55; Kobayashi et al. 2015), the NCEP Climate Forecast System Reanalysis (CFSR; Saha et al. 2010), and the NASA Modern-Era Retrospective Analysis for Research and Applications, version 2 (MERRA2; Gelaro et al. 2017). All of these products provide data over multiple decades and compare favorably with available observations (Bracegirdle and Marshall 2012). We focus on the surface easterly wind stress instead of wind velocity because wind stress more directly quantifies atmosphere-ocean momentum transfer and is thus more relevant to the wind-driven ocean circulation around the Antarctic margins. Note, however, that we are unable to distinguish between stress applied to the surface of the ocean and stress applied to the sea ice. While wind momentum imparted to sea ice may be transferred through to the ocean, densely packed sea ice that is immediately adjacent to land can also transfer momentum to the continent via internal stress (Leppäranta 2011).

The wind stress in ERA-Interim is calculated using the ECMWF bulk parameterization scheme (Renfrew et al. 2002). The ERA-Interim surface stress data have a spatial resolution of $0.75^{\circ} \times 0.75^{\circ}$ and spans the years $1979-2014$ (Dee et al. 2011). The sea ice, essential for proper flux measurements, is estimated by using the daily output from NCEP and the new global, operational, high-resolution, combined sea surface temperature (SST) and sea ice analysis system (OSTIA; Stark et al. 2007). In comparison with in situ measurements, ERA-Interim exhibits correlations in mean sea level pressure (MSLP) of greater than 0.98 and correlations between annualmean surface temperatures of 0.88 . ERA-Interim is the most accurate reanalysis dataset in its quantification of MSLP and geopotential height over Antarctica in the past three decades (1979-2008), with substantially smaller decadal-mean biases than other reanalysis products 
(Bracegirdle and Marshall 2012). ERA-Interim also most accurately reproduces the geostrophic winds around the Amundsen Sea when compared to other reanalysis products (Bracegirdle 2013).

For validation purposes, we calculate the easterly wind stress trend in MERRA2, CFSR, and JRA-55. All reanalysis products considered here use similar bulk parameterization schemes to assimilate wind speed observations. All products use a 3D variational assimilation method to compute air-sea fluxes from 6-hourly integrated fluxes that are based on roughness length parameterizations (Smith et al. 2011). The drag coefficients are derived from a modified Charnock formula and empirical stability functions. JRA-55 calculates the drag coefficient in a similar manner but does not include a stability term in the calculation of the Monin-Obukhov length scale. The $10-\mathrm{m}$ wind speed is used to calculate the wind stress values, so there are strong qualitative similarities between the calculated wind stress trends reported in section 3 and the 10-m wind speed trends, as discussed in the appendix. In the appendix, we reproduce a subset of our wind stress trend calculations using an independent estimate of the stresses derived from the $10-\mathrm{m}$ wind speeds via a simple quadratic bulk formula. These calculations demonstrate that the diagnosed trends are primarily due to changes in the winds, rather than, for example, changes in surface roughness because of changes in sea ice concentration.

Global reanalysis products remain at resolutions too coarse to resolve coastal features, and orography height biases contribute to errors in model temperature (Bracegirdle and Marshall 2012; Bromwich and Fogt 2004). Therefore, we additionally compare ERAInterim with the Antarctic Mesoscale Prediction System (AMPS; Powers et al. 2003, 2012), which spans 2006-15. AMPS does not provide surface stresses, so instead we compare the 10-m velocity fields (see Fig. A1). AMPS employs higher spatial resolution and is able to resolve a consistently swifter band of easterly winds around the Antarctic coast. Our comparison (see the appendix) shows that the enhancement of the alongshore winds in AMPS, relative to ERA-Interim, is typically higher than the diagnosed trends in the 30-yr ERA-Interim data. This is a caveat to the present study: It is likely that the magnitudes of the ERA-Interim trends reported in this study would change with a higher spatial resolution.

\section{b. Methods}

\section{1) WIND STRESS TRENDS}

We calculate the annual and seasonal linear trends in the zonal and meridional components of the wind stress over the 36-yr 1979-2014 ERA-Interim time span as well as the 1973-2012 JRA-55 (40 years), 1979-2015 MERRA2 (36 years), and 1980-2010 CFSR (31 years) datasets. Because of the variable latitudinal extent of the Antarctic coastline, neither the zonal nor the meridional components of the wind stress products provide a robust measure of the alongshore wind stress, which is arguably the most relevant for near-Antarctic circulation because it sets the cross-slope Ekman transport (Nøst et al. 2011; Stewart and Thompson 2015b; Zhou et al. 2014). We therefore additionally quantify the mean and trend of the wind stress directed along the Antarctic continental shelf break, which we define as the circumAntarctic 1000-m depth contour, taken from ETOPO-1 (Amante and Eakins 2009). We emphasize the component of the wind stress parallel to the Antarctic coast, as this component directly influences water mass exchanges across the continental slope (e.g., Thompson et al. 2014; Stewart and Thompson 2016). This also motivates our use of the 1000-m depth contour to define the Antarctic "coastline," as this consistently tracks the location of the continental shelf break.

To facilitate calculation of the along-slope winds, we derive a high-resolution 1000-m depth contour to represent the coastline from the ETOPO-1 bathymetric dataset (Amante and Eakins 2009). For compatibility with the spatial resolution of the ERA-Interim wind stress data, we approximate this contour as a series of piecewise-linear (in latitude-longitude space) sections of $1^{\circ}$ in length. We then interpolate and rotate the wind stress data in order to calculate the wind stress directed along each section. To compensate for our somewhat arbitrary selection of the 1000-m depth contour to define the coastline, we calculate the wind stress along each section as an average over a box that spans the length of the section and a prescribed width perpendicular to the section. More precisely, along each section we define a coordinate system $(s, n)$, in which the $s$ and $n$ coordinates lie parallel with and perpendicular to the section, respectively. We define a grid of points $\left(s_{i}, n_{j}\right)$, with $i=1, \ldots, M$ and $j=1, \ldots, N$, that spans the length $L$ of the section and a width $W$ perpendicular to the section. We then interpolate and rotate the wind stress to each point on this $M \times N$ grid. To create the plots in our manuscript, we use a grid of $M=10$ by $N=11$ points and average over the entire grid to calculate a single alongshore wind stress value for each section. Using finer discretizations (higher $M$ and/or $N$ ) does not change the calculated along-slope wind stress. We use a box width $W=100 \mathrm{~km}$ that is comparable to the width of the Antarctic continental slope (Amblas and Dowdeswell 2018). The exception is the inset in Fig. 1c, for which we use a box width of $W=400 \mathrm{~km}$ and average in the $s$ direction over all sections, in order to create an extended 
cross-slope profile of along-slope wind stress for comparison with the zonal-mean wind stress.

\section{2) INTERANNUAL VARIABILITY IN THE SAM AND THE POLE-TO-COAST PRESSURE GRADIENT}

Motivated by the impact of the SAM on the southwardshifting westerly winds and the hypothesized influence on the nearshore easterly wind stress, we calculate the correlations between the calculated interannual easterly wind stress trends and the calculated interannual $\Delta P_{\mathrm{SAM}}$. We develop the $\Delta P_{\text {SAM }}$ calculation based on the difference in the zonal MSLP between $40^{\circ}$ and $65^{\circ} \mathrm{S}$. We use the method described by Marshall (2003) to calculate this difference by linearly interpolating the MSLP from the reanalysis products (to the nearest $0.1^{\circ}$ ) to six observational stations at $40^{\circ} \mathrm{S}$ and six at $65^{\circ} \mathrm{S}$. These stations are listed in Table 2. In the interest of achieving a self-contained presentation, we use the mean of the six differences between the interpolated values at $40^{\circ}$ and $65^{\circ} \mathrm{S}$ to calculate $\Delta P_{\mathrm{SAM}}$.

Anticipating that the easterlies should also vary in response to the pole-to-coast pressure gradient that drives the katabatic winds, we define $\Delta P_{\text {Kat }}$, an analog of $\Delta P_{\mathrm{SAM}}$, to capture changes in this gradient; $\Delta P_{\mathrm{Kat}}$ is defined as the magnitude of the zonal MSLP between $85^{\circ}$ and $65^{\circ} \mathrm{S}$. In contrast to $\Delta P_{\mathrm{SAM}}$, this pressure difference is calculated using straightforward averages of the pressure around latitude circles. We find the MSLP at $85^{\circ}$ and $65^{\circ} \mathrm{S}$ and subtract the difference to find $\Delta P_{\text {Kat }}$. We note that ERA-Interim uses a bias-correction scheme to eliminate inconsistencies in the SLP measurements (Dee et al. 2011) that may exclude measurements of surface pressure on elevated terrain. However, its accuracy in reproducing pressure and temperature measurements close to the pole remains comparable to that close to the coast (Bracegirdle and Marshall 2012).

\section{Circum-Antarctic wind stress trends}

\section{a. Annual-mean wind stress trend}

Figures $2 \mathrm{a}$ and $2 \mathrm{~b}$ show the overall zonal and meridional wind stress trends calculated from ERA-Interim data. The most prominent feature of this trend is an enhanced eastward stress due to the strengthening of westerly winds, primarily between $45^{\circ}$ and $60^{\circ} \mathrm{S}$. This eastward strengthening approaches $0.05 \mathrm{~N} \mathrm{~m}^{-2}$ in the Pacific sector and bears a pattern that qualitatively resembles the first principal component of the SAM (e.g., Langlais et al. 2015). However, this eastward stress trend does not extend to the Antarctic coastline. With the exceptions of the western Ross Sea and the tip of the Antarctic Peninsula, the trend shows an enhanced westward wind stress along the coast. There are also
TABLE 2. Meteorological station locations used to calculate $\Delta P_{\text {SAM }}$.

\begin{tabular}{lcr}
\hline \multicolumn{1}{c}{ Station name } & Lat $\left({ }^{\circ} \mathrm{S}\right)$ & Lon $\left({ }^{\circ} \mathrm{E}\right)$ \\
\hline Marion Island & 46.9 & 37.9 \\
Ile Nouvelle Amsterdam & 37.8 & 77.5 \\
Hobart & 42.9 & 147.3 \\
Christchurch & 43.5 & 172.6 \\
Valdivia & 39.6 & -73.1 \\
Gough Island & 40.4 & -9.9 \\
Novolazarevska & 70.8 & 11.8 \\
Mawson & 67.6 & 62.9 \\
Mirny & 66.6 & 93.0 \\
Casey & 66.3 & 110.5 \\
Dumont D'Urville & 66.7 & 140.0 \\
Faraday/Vernadsky & 65.2 & -64.3 \\
\hline
\end{tabular}

substantial regional variations in the amplitude of this strengthening trend, with the area around the Amery Ice Shelf exhibiting a particularly pronounced intensification of the westward stress over this time period.

Figures $2 \mathrm{c}$ and $2 \mathrm{~d}$ show the trend in the alongshore wind stress (defined positive for a "westerly" or cyclonic trend) as a function of alongshore distance and mapped onto the 1000-m depth contour, respectively. This trend further suggests that the annual-mean easterly wind stress around the Antarctic coast is strengthening, albeit weakly, which is contrary to the expected weakening associated with the SAM. Averaged around the coastline, the easterly wind stress increased in magnitude by $0.0044 \mathrm{~N} \mathrm{~m}^{-2}$ from 1979 to 2014 . Note, however, that this strengthening is not statistically significant at the $5 \%$ level ( $p=0.25$; see Table 4$)$. The exceptions to this easterly trend are found in the northwestern Ross and northwestern Weddell Seas. This is largely due to a northerly meridional wind stress trend in these regions that acts to reduce the strength of the katabatic winds that drive the easterlies.

\section{b. Trend in the seasonal cycle}

The pronounced seasonal cycle around Antarctica (Meehl 1991; Simmonds and Jones 1998; Mathiot et al. 2011; Wang et al. 2012; Gordon 1981) warrants a calculation of the trends in the seasonally averaged wind stress. Figures 3 and 4 show the seasonal breakdown of the zonal/meridional and alongshore wind stress trends. There are pronounced local variations in the signs and amplitudes of the alongshore trends in Fig. 3. For example, in Fig. 2, we find a weakening of the easterlies in the western Ross Sea and the western Weddell Sea. Figures $3 \mathrm{a}$ and $3 \mathrm{c}$ show that the weakening is statistically significant in DJF in the western Weddell Sea and in DJF and MAM in the Ross Sea. Austral summer and autumn also have significant northerly strengthening trends in these regions, which will augment the trend 
ERA-Interim Multi-Decadal Zonal Wind Stress Trend
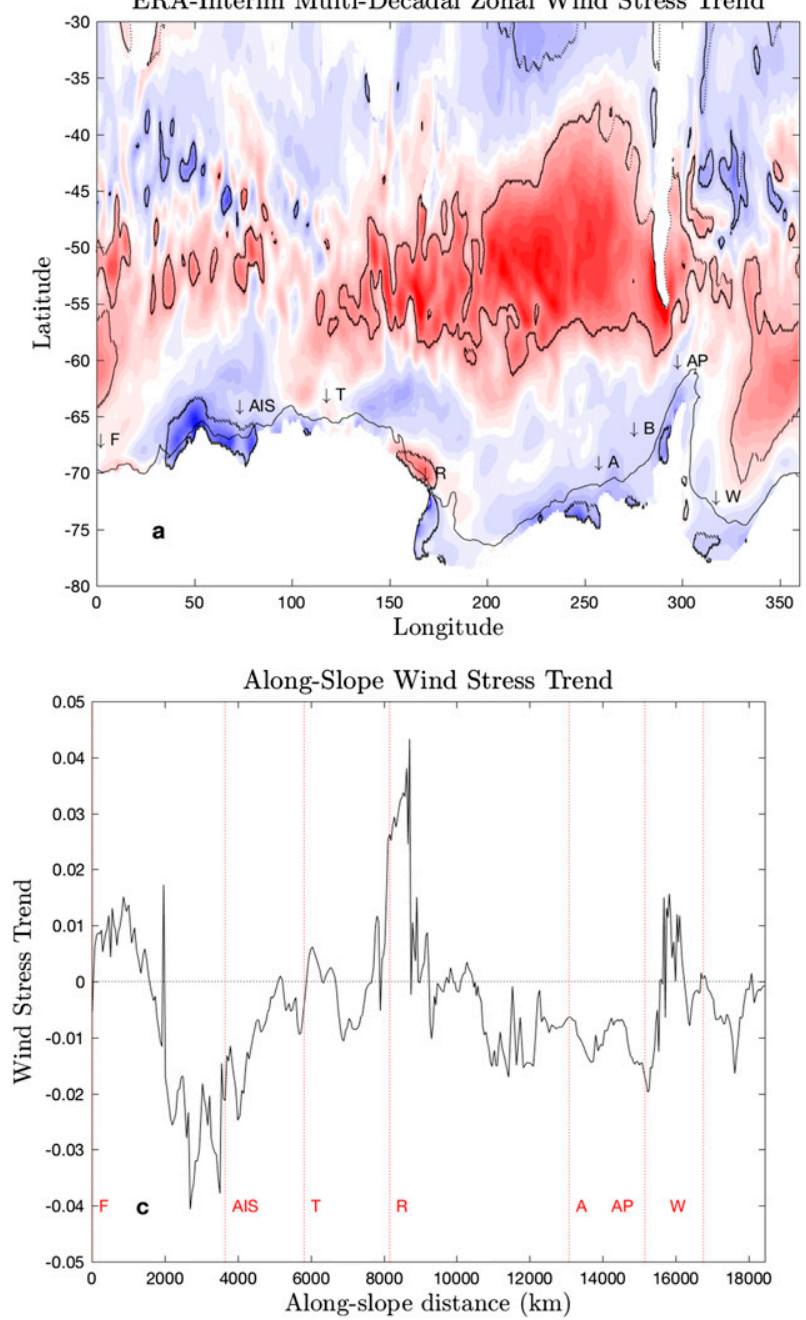

Meridional Wind Stress Trend
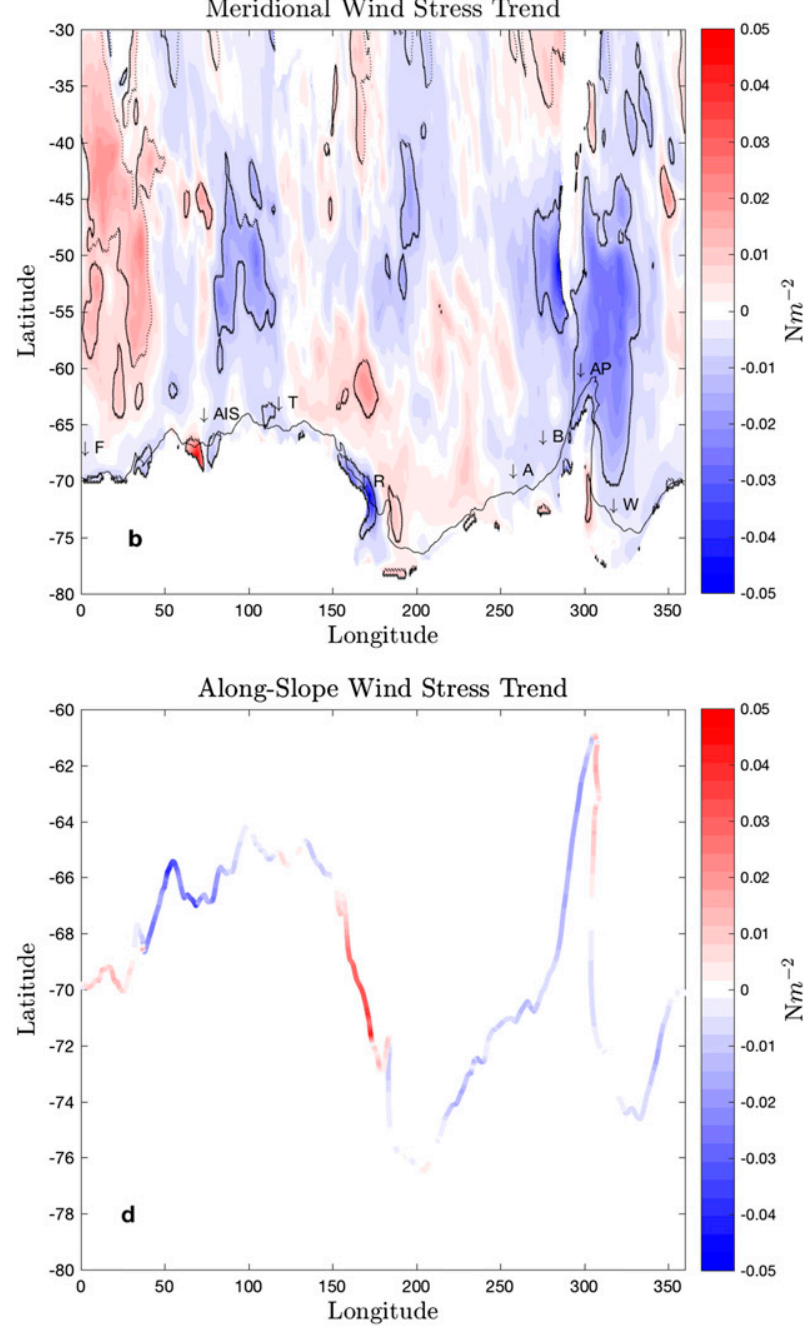

FIG. 2. Multidecadal trends in the mean surface wind stress $\left(\mathrm{N} \mathrm{m}^{-2}\right)$ around the Antarctic margins from 1979-2014 ERA-Interim data (Dee et al. 2011). Black contours envelop regions that are statistically significant at the $5 \%$ level. (a) Mean zonal wind stress trend ( $\mathrm{N} \mathrm{m}^{-2}$ ), (b) mean meridional wind stress trend $\left(\mathrm{N} \mathrm{m}^{-2}\right)$, and (c),(d) along-slope wind stress trend as a function of along-slope distance and mapped onto the 1000-m depth contour.

of weakening circumpolar-averaged anticyclonic wind stress. In contrast, parts of East Antarctica show a strengthening of the prevailing easterly wind stress trend in all seasons, with this trend being significant in all seasons at the $5 \%$ level with the exception of DJF.

Figures 3 and 4 both visually suggest an overall pattern of austral summer weakening and austral winter strengthening of the prevailing easterly winds. More quantitatively, from 1979 to 2014, DJF and MAM exhibit weakening trends of magnitudes of $0.0055 \mathrm{~N} \mathrm{~m}^{-2}(p=0.26)$ and $0.0022 \mathrm{~N} \mathrm{~m}^{-2} p=0.26(p=0.76)$, respectively (see Table 4). The SAM has been shown to be most positive in DJF and MAM (Marshall 2003), consistent with the widespread enhancement of the westerly wind stress visible in Figs. 3a and 3c. This westerly anomaly is compensated in JJA and SON by strengthening of the prevailing easterly wind stress trends of $0.0112 \mathrm{~N} \mathrm{~m}^{-2}(p=0.17)$ and $0.0143 \mathrm{~N} \mathrm{~m}^{-2}(p=0.03)$, respectively. Figures $3 \mathrm{e}$ and $3 \mathrm{~g}$ show widespread easterly wind stress anomalies, particularly close to the Antarctic coast. In various locations, these easterly trends are accompanied by strong southerly wind stress anomalies within a few latitudinal degrees of the coast, visible in Figs. $3 \mathrm{f}$ and $3 \mathrm{~h}$, suggesting that the trend toward stronger winter easterlies may be associated with stronger katabatic winds.

In summary, the annual-mean circumpolar alongshore wind stress trends are small but indicate a slight strengthening of the easterlies, in contrast to the expected weakening due to enhancement of the SAM. However, 

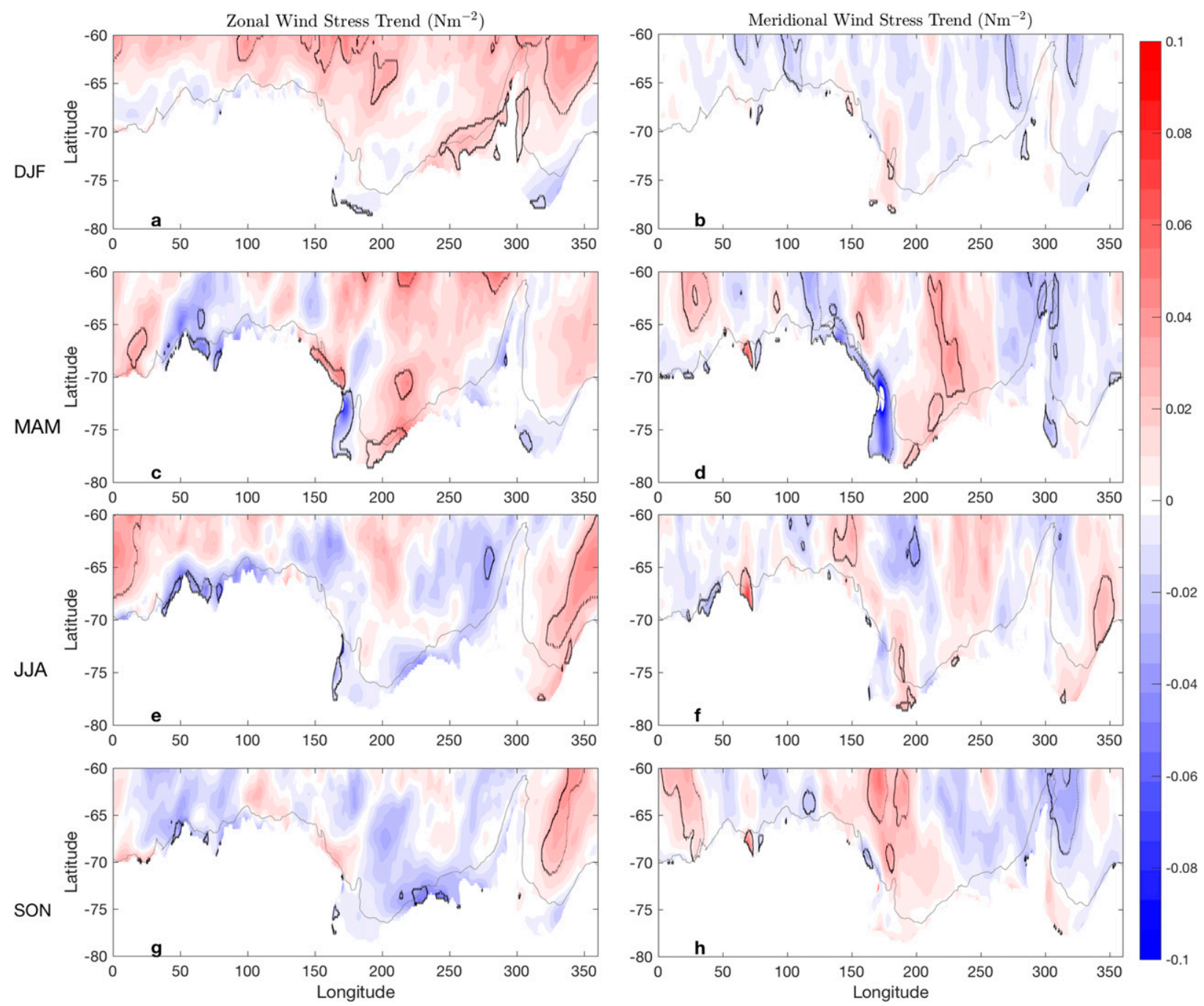

FIG. 3. Multidecadal trends in the seasonal-mean zonal and meridional wind stress (in N m ${ }^{-2}$ ) calculated from 1979-2014 ERA-Interim data (Dee et al. 2011). Black contours envelop trends that are statistically significant at the $10 \%$ level. (a) DJF zonal wind stress trend, (b) DJF meridional wind stress trend, (c) MAM zonal wind stress trend, (d) MAM meridional wind stress trend, (e) JJA zonal wind stress trend, (f) JJA meridional wind stress trend, (g) SON zonal wind stress trend, and (h) SON meridional wind stress trend.

the trends are regionally and seasonally much larger, notably in DJF and SON, in the Amundsen and East Antarctic sectors. At the continental scale, this implies a trend toward a larger seasonal cycle (see Fig. 4j), with a weakening of the alongshore easterlies in summer and a strengthening in winter. We discuss implications of this trend in section 4 .

\section{c. Attribution of the circum-Antarctic wind stress trends}

The trends in the circumpolar wind stress in ERAInterim show a weakening during austral summer and autumn and a strengthening during austral winter and spring. As stated previously, the high-index polarity of the SAM is characterized by lower pressure at midlatitudes with higher pressures and cold temperatures over the Antarctic continent (Thompson and Solomon 2002; Shindell and Schmidt 2004). Periods of anomalously cold temperatures are also associated with slopeinversion pressure gradients in interior East Antarctica (Kodama and Wendler 1986). We now examine both multidecadal variations in $\Delta P_{\mathrm{SAM}}$ and in the poleto-coast pressure gradient $\Delta P_{\text {Kat }}$ to determine the extent to which the coastal wind trends can be related to these indicators of Southern Hemisphere climate variability.

Figure 5 shows the seasonal trend in the ERA-Interim $\Delta P_{\mathrm{SAM}}, \Delta P_{\mathrm{Kat}}$, and the circumpolar easterly wind stress trend with the corresponding Pearson's correlation coefficients $r$. Figures $5 \mathrm{a}$ and $5 \mathrm{~b}$ show that the increase in 

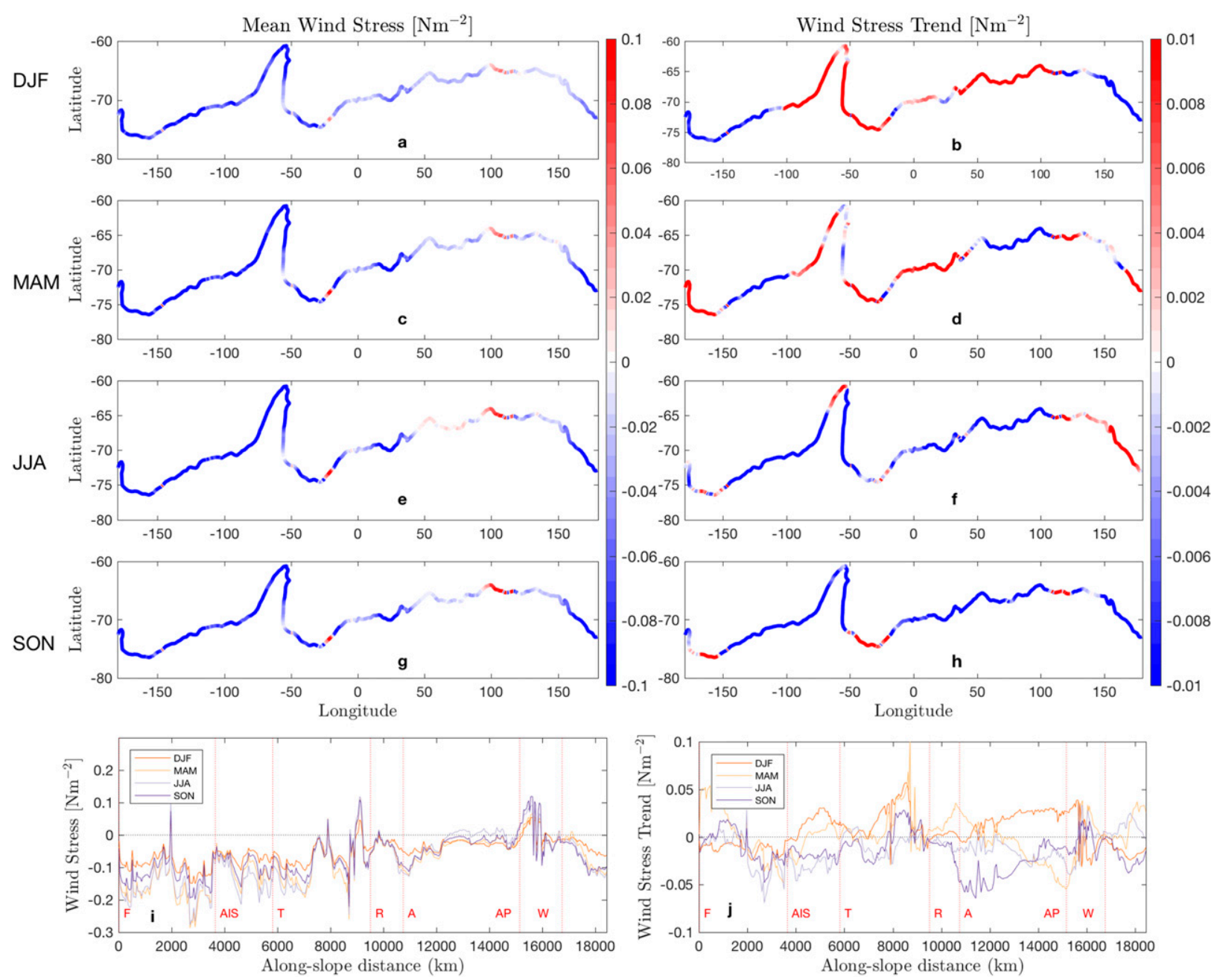

FIG. 4. Multidecadal mean and trend of the seasonal-mean along-slope wind stress $\left(\mathrm{N} \mathrm{m}^{-2}\right)$, from 1979-2014 ERA-Interim data (Dee et al. 2011). (a) DJF mean, (b) DJF trend, (c) MAM mean, (d) MAM trend, (e) JJA mean, (f) JJA trend, (g) SON mean, and (h) SON trend. (i),(j) Compilation of the mean and trend of along-slope wind stress, respectively, as functions of along-slope distance.

$\Delta P_{\text {SAM }}$ is largest during DJF and MAM and is accompanied by a weakening of the easterly wind stress, particularly in DJF. In contrast, SON shows a weakened $\Delta P_{\text {SAM }}$ and a strengthened easterly wind stress accompanied by a strengthening of $\Delta P_{\text {Kat }}$. All seasons demonstrate a positively correlated circumpolar-averaged westerly wind stress with $\Delta P_{\text {SAM }}$ (equivalent to a negative correlation between circumpolar-averaged easterly wind stress with $\Delta P_{\text {SAM }}$ ) and a negatively correlated circumpolar-averaged westerly wind stress and $\Delta P_{\mathrm{Kat}}$ (equivalent to a positive correlation between circumpolaraveraged easterly wind stress and $\Delta P_{\text {Kat }}$ ). The interannual correlations between $\Delta P_{\mathrm{Kat}}$ and the easterly wind stress are consistently stronger. Thus, positive $\Delta P_{\mathrm{SAM}}$ and $\Delta P_{\text {Kat }}$ periods are typically accompanied by weakening and strengthening of the easterly wind stress, respectively.
To attribute the long-term seasonal trends in the alongshore wind stress, we now consider seasonal trends in $\Delta P_{\text {Kat }}$ and $\Delta P_{\text {SAM }}$. We list the seasonal $\Delta P_{\text {Kat }}$ and $\Delta P_{\mathrm{SAM}}$ trends and the seasonal wind stress trends in Table 3 with their corresponding $p$ values. The trend in $\Delta P_{\text {SAM }}$ is positive in all seasons except for SON. In DJF, $\Delta P_{\mathrm{SAM}}$ has its greatest trend of $12.74 \mathrm{hPa}$ century $^{-1}$, with a significance of $1 \%$. However, DJF is the only season where $\Delta P_{\text {SAM }}$ is significant at less than $10 \%$. In terms of $\Delta P_{\mathrm{Kat}}$, we see positive trends in JJA and SON, but these trends lack significance. This supports the hypothesis that multidecadal weakening of the easterlies in DJF is associated with the calculated increase in $\Delta P_{\text {SAM }}$. In SON, although $\Delta P_{\text {SAM }}$ has decreased, its trend is not statistically significant and so cannot explain the intensification of the easterlies. In contrast, $\Delta P_{\text {Kat }}$ exhibits its strongest trend in SON, 

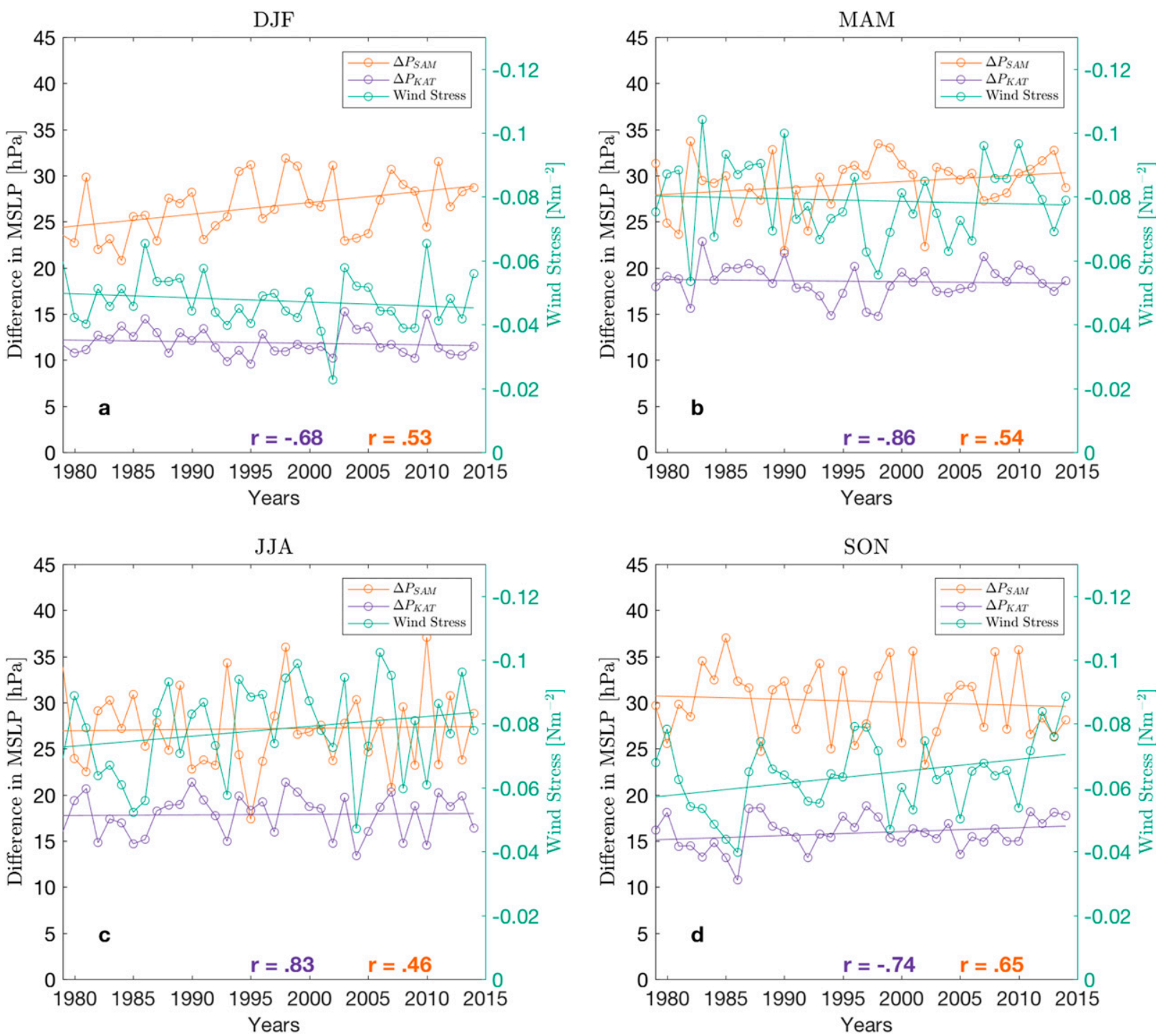

FIG. 5. The seasonal breakdown (a) DJF, (b) MAM, (c) JJA, and (d) SON of the multidecadal trend in the $\Delta P_{\mathrm{SAM}}$ and $\Delta P_{\mathrm{Kat}}$ from 1979 2014 ERA-Interim data (Dee et al. 2011). We calculate $\Delta P_{\text {SAM }}$ (orange) as the difference in the MSLP from six observational stations at $40^{\circ}$ and $65^{\circ} \mathrm{S}$ that are interpolated to the nearest $0.1^{\circ}$. We calculate $\Delta P_{\text {Kat }}$ (purple) as the difference in the MSLP between $85^{\circ}$ and $65^{\circ} \mathrm{S}$. Superimposed on $\Delta P_{\mathrm{SAM}}$ and $\Delta P_{\mathrm{Kat}}$ are their trends, the mean along-slope annual wind stress $\left(\mathrm{N} \mathrm{m}^{-2}\right.$; green), and the trend in the mean seasonal along-slope wind stress $\left(\mathrm{N} \mathrm{m}^{-2}\right)$. The correlation between the mean seasonal $\Delta P_{\mathrm{SAM}}$ and $\Delta P_{\mathrm{Kat}}$ with the along-slope wind stress $\Delta P_{\text {Kat }}$ is provided on the bottom of each plot.

strengthening by $4.04 \mathrm{hPa}$ century ${ }^{-1}$. This trend is marginally insignificant at the $10 \%$ level $(p=0.11)$, despite the strong interannual correlation $r=-.74$, because of the large amplitude of the interannual fluctuations in
$\Delta P_{\text {Kat }}$. Thus, while the trends suggest a relationship between intensification of both $\Delta P_{\text {Kat }}$ and the easterlies in SON, an unambiguous attribution is not possible based on our analysis.

TABLE 3. ERA-Interim seasonal trends in the circumpolar-averaged alongshore wind stress and meridional pressure gradients with the corresponding $p$ values as superscripts; $p$ values in bold are significant at $10 \%$.

\begin{tabular}{|c|c|c|c|c|}
\hline Trend & DJF & MAM & JJA & SON \\
\hline Wind stress trend $\left(\mathrm{N} \mathrm{m}^{-2}\right.$ century $\left.^{-1}\right]$ & $0.015^{0.26}$ & $0.006^{0.76}$ & $-0.031^{0.17}$ & $-0.040^{\mathbf{0 . 0 3}}$ \\
\hline$\Delta P_{\text {SAM }}$ trend $\left(\right.$ hPa century $\left.{ }^{-1}\right)$ & $12.74^{\mathbf{0 . 0 1}}$ & $6.86^{0.19}$ & $1.32^{0.95}$ & $-3.28^{0.48}$ \\
\hline$\Delta P_{\text {Kat }}$ trend $\left(\mathrm{hPa}\right.$ century $\left.{ }^{-1}\right)$ & $-1.68^{0.44}$ & $-2.05^{0.77}$ & $0.369^{0.68}$ & $4.04^{0.11}$ \\
\hline
\end{tabular}



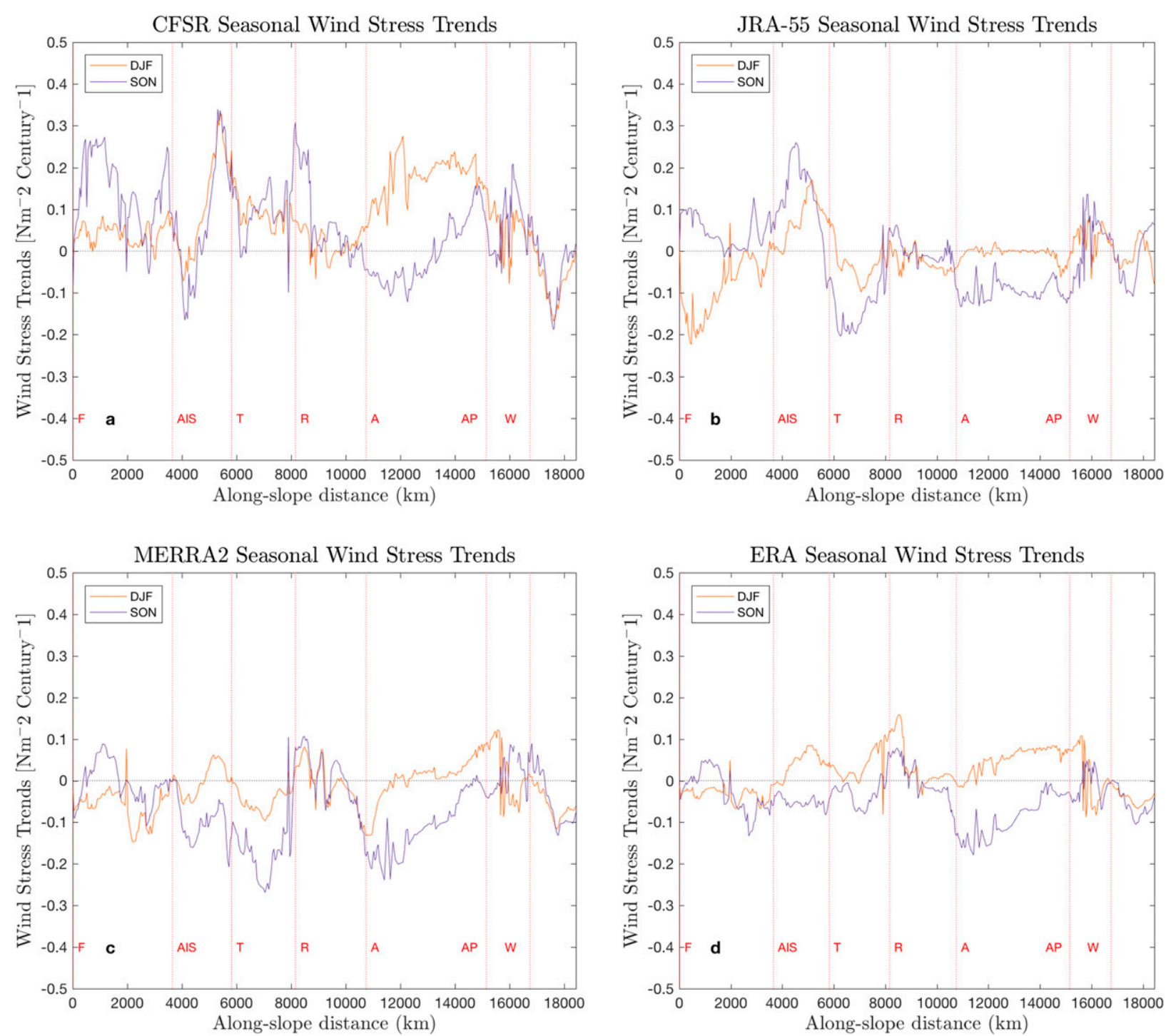

FIG. 6. Multidecadal DJF and SON along-slope circumpolar wind stress ( $\mathrm{N} \mathrm{m}^{-2}$ century $^{-1}$ ) trends from (a) 1980-2010 CFSR (Saha et al. 2010), (b) 1972-2013 JRA-55 (Kobayashi et al. 2015), (c) 1980-2015 MERRA2 (Gelaro et al. 2017) data, and (d) 1979-2014 ERA (Dee et al. 2011) products. Red labels indicate reference points to aid geographical interpretation. See Table 1 for further details.

In summary, a combined consideration of interannual correlations between the large-scale pressure gradients $\Delta P_{\mathrm{SAM}}$ and $\Delta P_{\mathrm{Kat}}$, combined with the linear multidecadal trends given in Table 3, suggest two connections: intensification of the DJF $\Delta P_{\text {SAM }}$ with weakening of the easterlies and intensification of the SON $\Delta P_{\text {Kat }}$ with strengthening of the easterlies. However, pronounced interannual variability renders only the DJF $\Delta P_{\mathrm{SAM}}$ trend and SON wind stress trend significant at the $10 \%$ level, so there remains some ambiguity as to the drivers of the wind stress trends. The complexity of the dynamics near Antarctica implies that our calculated trends may be influenced by other phenomena, such as the semiannual oscillation (SAO), related to semiannual expansion and contraction of cyclonic activity in the mid- and high Southern Hemisphere latitudes (Meehl 1991; Simmonds and Jones 1998).

\section{d. Consistency among reanalysis products}

As outlined in section 2a, ERA-Interim is used to quantify the trend in the multidecadal easterly wind stress and provides the closest comparison to Antarctic meteorological stations (Bracegirdle and Marshall 2012). However, as stated previously, reanalysis data are less constrained by observations in high latitudes than in other parts of the world (Dee et al. 2011). Therefore, we check the consistency in the diagnosed trends of $\Delta P_{\mathrm{SAM}}, \Delta P_{\mathrm{Kat}}$, and the easterly wind stress across three 

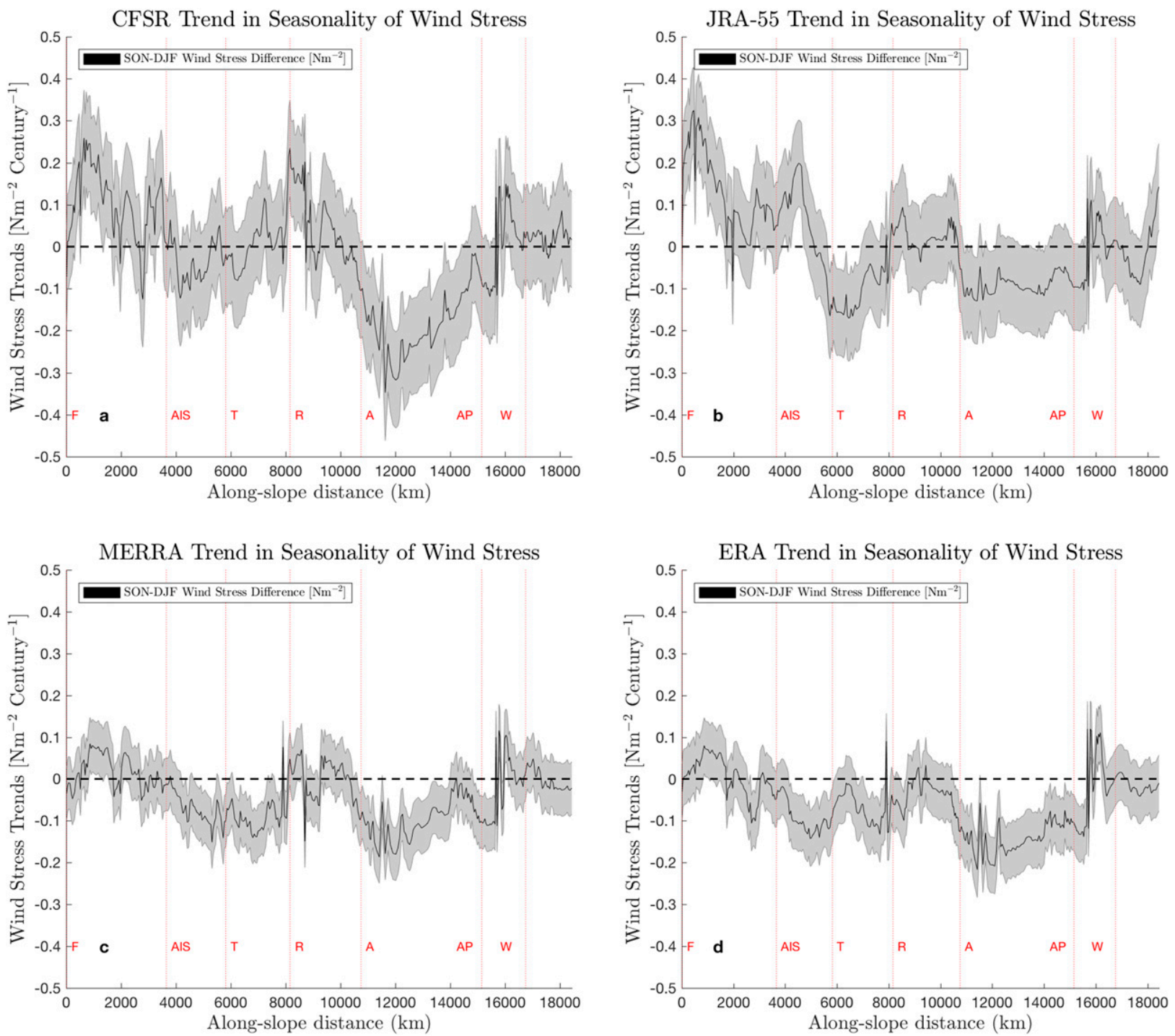

FIG. 7. Multidecadal trends in the SON-DJF wind stress difference $\left(\mathrm{N} \mathrm{m}^{-2}\right.$ century $\left.{ }^{-1}\right)$ as a function of along-slope distance, error bars are standard deviations from the multidecadal mean SON-DJF wind stress for (a) 1980-2010 CFSR (Saha et al. 2010), (b) 1972-2013 JRA55 (Kobayashi et al. 2015), (c) 1980-2015 MERRA2 (Gelaro et al. 2017), and (d) 1979-2014 ERA-Interim (Dee et al. 2011) products. Red labels indicate reference points to aid geographical interpretation. See Table 1 for further details.

other reanalysis products: JRA-55 (Kobayashi et al. 2015), CFSR (Saha et al. 2010), and MERRA2 (Gelaro et al. 2017), selected because they perform comparably to one another in reproducing measurements from meteorological stations, though not as well as ERA-Interim (Bracegirdle and Marshall 2012).

Figure 6 compares the multidecadal seasonal wind stress trends from the four reanalysis products during DJF and SON, the seasons that exhibit the strongest and most significant trends in ERA-Interim. As expected, all trends differ quantitatively from one another. Aside from CFSR, all products also demonstrate a strengthening of the easterly wind stress during SON.
Moreover, all four products capture the divergence between the DJF and SON trends, implying that all products exhibit a widening of the gap between the weaker DJF easterly wind stress and the stronger SON easterly wind stress. This enhancement appears to be concentrated in approximately the same sectors of the Antarctic coastline. For instance, the Amundsen region shows a stronger change in the difference of the wind stress trend between DJF and SON, consistent with the deepening of the Amundsen Sea low (ASL; Turner et al. 2013).

To visualize the regional variations of the changes in seasonality and their amplitude compared to the 
TABLE 4. Trends in the circumpolar-averaged alongshore wind stress and meridional pressure gradients with the corresponding statistical $p$ values in the superscript of each trend; $p$ values in bold are significant at $10 \%$.

\begin{tabular}{|c|c|c|c|c|}
\hline Variable & ERA-Interim & MERRA2 & CFSR & JRA-55 \\
\hline Mean annual wind stress trend $\left(\mathrm{N} \mathrm{m}^{-2}\right.$ century $\left.^{-1}\right)$ & $-0.012^{0.25}$ & $-0.045^{\mathbf{0 . 0 0 7}}$ & $0.058^{\mathbf{0 . 0 0 6}}$ & $-0.002^{0.81}$ \\
\hline DJF wind stress trend $\left(\mathrm{N} \mathrm{m}^{-2}\right.$ century $\left.^{-1}\right)$ & $0.015^{0.26}$ & $-0.022^{0.15}$ & $0.068^{\mathbf{0 . 0 6}}$ & $-0.011^{0.30}$ \\
\hline DJF $\Delta P_{\text {SAM }}\left(\right.$ hPa century $\left.^{-1}\right)$ & $12.7^{\mathbf{0 . 0 1}}$ & $11.1^{\mathbf{0 . 0 2}}$ & $8.19^{0.20}$ & $20.0^{\mathbf{0 . 0 0 0 0 3}}$ \\
\hline DJF $\Delta P_{\text {Kat }}\left(\right.$ hPa century $\left.{ }^{-1}\right)$ & $-1.68^{0.44}$ & $-6.57^{0.001}$ & $-1.48^{0.66}$ & $1.40^{0.85}$ \\
\hline SON wind stress trend $\left(\mathrm{N} \mathrm{m}^{-2}\right.$ century $\left.{ }^{-1}\right)$ & $-0.04^{0.03}$ & $-0.056^{\mathbf{0 . 0 4}}$ & $0.061^{\mathbf{0 . 0 4}}$ & $-0.010^{0.40}$ \\
\hline SON $\Delta P_{\text {SAM }}\left(\right.$ hPa century $\left.^{-1}\right)$ trend & $-3.28^{0.48}$ & $-5.56^{0.27}$ & $-2.09^{0.78}$ & $12.9^{\mathbf{0 . 0 1 3}}$ \\
\hline SON $\Delta P_{\text {Kat }}\left(\mathrm{hPa}\right.$ century $\left.{ }^{-1}\right)$ trend & $4.04^{0.11}$ & $8.28^{\mathbf{0 . 0 1}}$ & $1.92^{0.54}$ & $4.73^{\mathbf{0 . 0 2}}$ \\
\hline
\end{tabular}

interannual variability, Fig. 7 shows the difference in the SON and DJF wind stress trends as a function of distance along the Antarctic slope. Here, it is clear that the magnitude of the change in the seasonality of the wind stress depends highly on location. Areas that visually have large summer-to-winter diverging seasonal cycles, especially the Amundsen and East Antarctic region, exhibit the largest trends in the SON-DJF wind stress changes. One caveat specific to the Amundsen region is the impact of ENSO on the depth of the ASL in winter and spring (Clem et al. 2016), which may be a driver of our calculated trends during these seasons.

Table 4 summarizes the annual-mean wind stress trends, the DJF and SON wind stress trends, and the $\Delta P_{\mathrm{SAM}}$ and $\Delta P_{\mathrm{Kat}}$ trends in SON and DJF. Aside from CFSR, all products exhibit annual-mean strengthened easterly wind stress trends. CFSR has been shown to have persistent high-temperature biases during winter (Bracegirdle and Marshall 2012), which may contribute to differing wind stress trends in the multidecadal and seasonal analyses. In addition, all reanalysis products exhibit a DJF weakening of the easterly wind stress along with a DJF increase of $\Delta P_{\mathrm{SAM}}$. Aside from CFSR, all products have a linear trend in the $\Delta P_{\text {SAM }}$ that is increasing with a significance of less than $10 \%$. We plot the DJF and SON wind stress trends of CFSR, MERRA2, JRA-55, and ERA-Interim in conjunction with the calculated DJF $\Delta P_{\text {SAM }}$ and $\Delta P_{\text {Kat }}$ in Fig. 8. Similarly to ERAInterim, all reanalysis products show positive interannual correlations, which implies an eastward anomaly with a strengthened $\Delta P_{\text {SAM }}$. This supports a connection between strengthening of the SAM and weakening of the easterlies in austral summer.

Table 4 reveals that during SON, all products except for CFSR show an increase of strength in the easterly wind stress and an increase in $\Delta P_{\text {Kat }}$. CFSR is an outlier among the products in that it exhibits a weakening, rather than strengthening, of the easterlies and $\Delta P_{\mathrm{Kat}}$ in SON. The SON trends in $\Delta P_{\text {Kat }}$ are significant in MERRA2 and JRA-55 at $1 \%$ and $2 \%$, respectively. While MERRA2 also exhibits a stronger intensification of the SON easterlies $\left(-0.056 \mathrm{~N} \mathrm{~m}^{-2}\right.$ century $\left.^{-1}, p=0.04\right)$, the SON intensification of $\Delta P_{\mathrm{Kat}}$ in JRA-55 is not accompanied by a statistically significant enhancement of the easterlies. MERRA2 is therefore the only product with a positive SON trend in $\Delta P_{\text {Kat }}$ and a stronger intensification of the SON easterlies, which is significant.

Similarly to Fig. 8, Fig. 9 compares the SON easterly wind stress trends and the calculated $\Delta P_{\text {Kat }}$ trends. Figure 9 shows that the katabatic winds have the smallest interannual correlation with the wind stress in CFSR. In the other products, the variations in the $\Delta P_{\text {Kat }}$ can explain about $50 \%$ of the variance in the interannual wind stress trends. MERRA2, CFSR, and JRA-55 therefore generally support the relationships between $\Delta P_{\mathrm{SAM}}, \Delta P_{\text {Kat }}$, and the easterly wind stress inferred from ERA-Interim, though with substantial discrepancies that might be expected based on these products' lower accuracy in reproducing meteorological measurements (Bracegirdle and Marshall 2012).

\section{Implications of increased alongshore wind seasonality for near-Antarctic circulation}

In section 1, we provided an overview of the impacts of the easterly winds on near-Antarctic circulation. In our results in section 3, we found that the annual-mean wind stress has not changed significantly, but that the seasonality of the wind stress has changed substantially. For example, Fig. 6d shows that the ERA-Interim DJF and SON wind stresses have diverged from one another, with strengthening easterly wind stress in SON and weakening easterly wind stress in DJF. Figure 8 demonstrates the consistency among reanalysis products, and each shows an enhancement of the wind stress difference between DJF and SON.

An increase in the seasonality of the wind stress may have consequences for several aspects of the nearAntarctic circulation. For instance, ice motion trends during autumn, especially in the Pacific and Atlantic sectors of the Antarctic coast, are strongly correlated to the changes in the autumn 10-m wind forcing (Holland and Kwok 2012). Other potential impacts of the nearAntarctic winds on the circulation include changes 

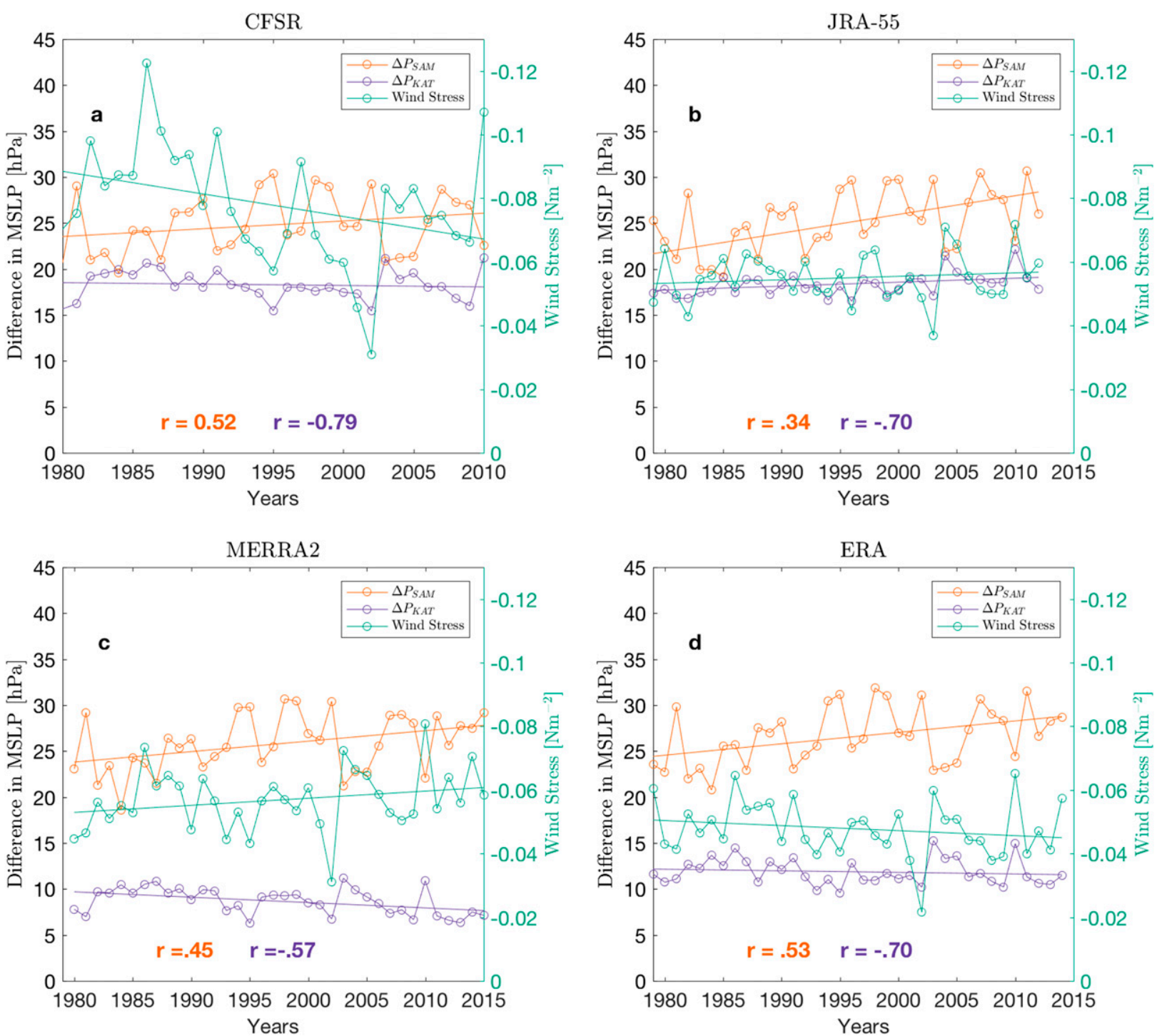

FIG. 8. Multidecadal trends in DJF for (a) 1980-2010 CFSR (Saha et al. 2010), (b) 1973-2012 JRA-55 (Kobayashi et al. 2015), (c) 19792015 MERRA2 (Gelaro et al. 2017), and (d) 1979-2014 ERA (Dee et al. 2011) products. The DJF $\Delta P_{\text {SAM }}$ (hPa; orange dots) is plotted with the superimposed DJF $\Delta P_{\mathrm{SAM}}$ trend (orange line). The DJF $\Delta P_{\mathrm{Kat}}\left(\mathrm{hPa}\right.$; purple dots) is plotted with the superimposed DJF $\Delta P_{\mathrm{Kat}}$ trend (purple line). On the right $y$ axis, the DJF mean wind stress is plotted (green; $\mathrm{N} \mathrm{m}^{-2}$ ) with the superimposed trend (green line). The correlations between the mean seasonal $\Delta P_{\mathrm{SAM}}$ and $\Delta P_{\text {Kat }}$ with the along-slope wind stress are provided in their respective colors.

in AABW export, changes in the properties of AABW, and variability in heat transport toward ice shelves.

Easterly winds modify the rate of AABW formation and export (Jullion et al. 2010; Wang et al. 2012; Su et al. 2014), a process that has global-scale impacts for ocean circulation (Marshall and Speer 2012). Stronger easterly winds in the southern Weddell and Ross Seas (see Fig. 2) enhance the export of dense shelf water simply by virtue of a stronger shoreward Ekman transport and deep offshore return flow (Stewart and Thompson 2012, 2013) and/or by depressing the pycnocline at the shelf break and enhancing the overflow through the Filchner
Trough (Kida 2011; McKee et al. 2011). The wind stress trends shown in Fig. 2 may also be expected to produce a stronger baroclinicity of the Weddell and Ross Gyres (McKee et al. 2011). Export of dense water would be enhanced as an effect of stronger thermal wind forcing. A stronger gyre would promote a doming of isopycnals in the center of the gyre and a deepening of isopycnals at the gyre rim (Jullion et al. 2010).

The seasonal trends (Fig. 4), as well as the enhancement of the seasonal cycle in the strength of the easterly winds (Fig. 6), project onto the mechanisms that form and export dense water from Antarctica. Weddell Sea 

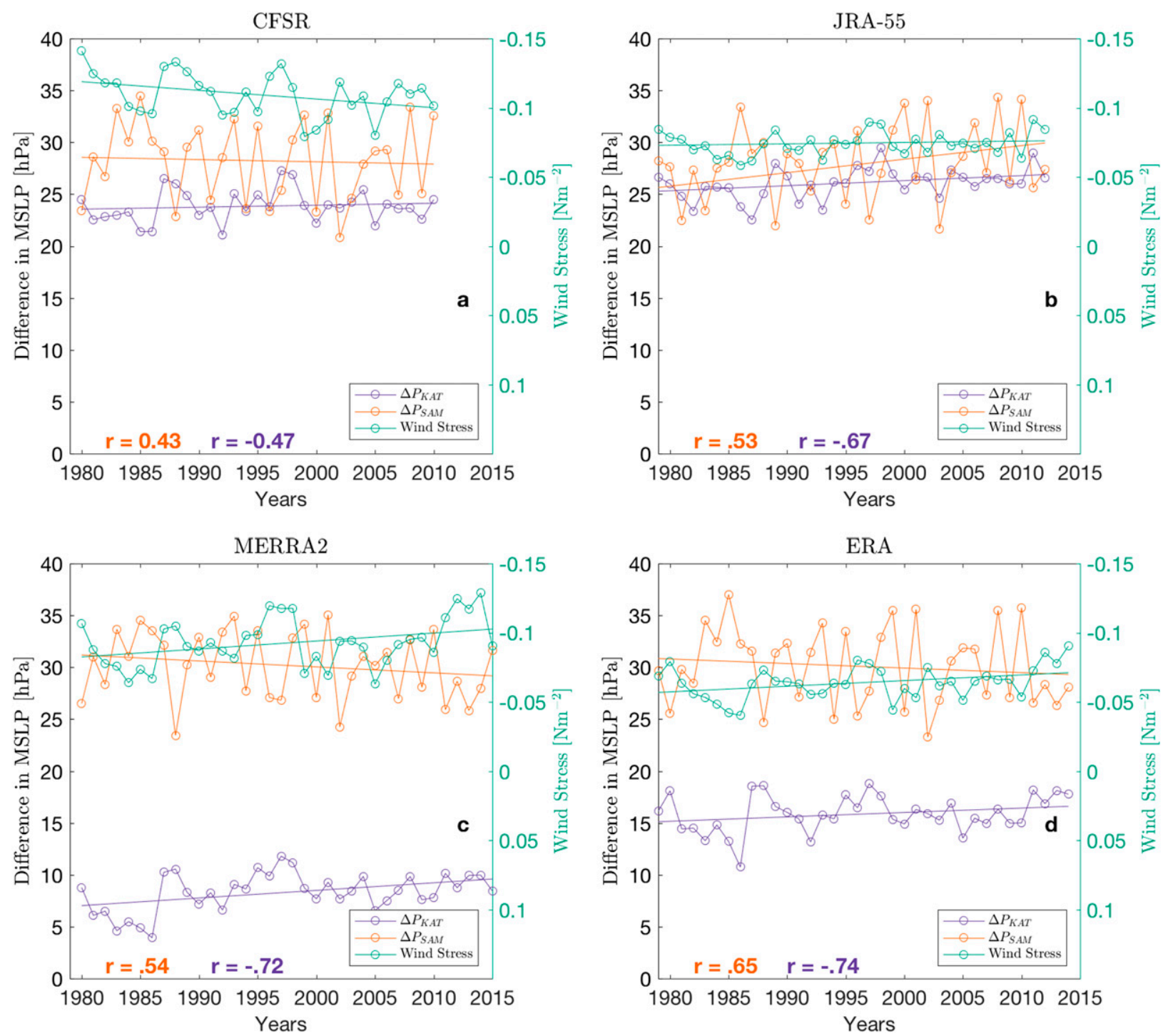

FIG. 9. Multidecadal trends in SON for (a) 1980-2010 CFSR (Saha et al. 2010), (b) 1973-2012 JRA-55 (Kobayashi et al. 2015), (c) 1979_ 2015 MERRA2 (Gelaro et al. 2017), and (d) 1979-2014 ERA (Dee et al. 2011) products. The SON $\Delta P_{\text {SAM }}$ (hPa; orange dots) is plotted with the superimposed SON $\Delta P_{\mathrm{SAM}}$ trend (orange line). The SON $\Delta P_{\mathrm{Kat}}\left(\mathrm{hPa}\right.$; purple dots) is plotted with the superimposed SON $\Delta P_{\mathrm{Kat}}$ trend (purple line). On the right $y$ axis, the SON mean wind stress is plotted (green dots; $\mathrm{N} \mathrm{m}^{-2}$ ) with the superimposed trend (green line). The correlations between the mean seasonal $\Delta P_{\mathrm{SAM}}$ and $\Delta P_{\text {Kat }}$ with the along-slope wind stress are provided in their respective colors.

Bottom Water (WSBW) and Weddell Sea Deep Water (WSDW) are precursors to AABW in the Weddell Sea. The export of these dense water masses from the Filchner Trough and the transport toward the Antarctic Peninsula is mediated by seasonal variations in the along-slope winds (Wang et al. 2012). Additionally, a change in wind stress seasonality may influence export of WSDW northward from the deep Weddell Gyre via the Orkney Passage by modulating the seasonal cycle in the gyre's baroclinicity (Meredith et al. 2008; Su et al. 2014). AABW export reaches a peak outflow from the Weddell Gyre in austral autumn and a minimum in austral spring (Gordon et al. 2010). Therefore, an increase (decrease) in the easterlies in austral autumn (spring) may lead to an increase (decrease) in AABW export.

Properties of AABW are closely tied to the seasonal circum-Antarctic wind forcing. In the Ross Sea, winter intensification of the winds shifts the Antarctic Slope Front poleward and suppresses high-salinity shelf water (HSSW) export (Gordon et al. 2015), a process that may have intensified as a result of the SON enhancement of the easterlies. Warm and fresh bottom water is produced with an increase in the strength of the easterlies, which is in contrast to the cold, salty bottom water 

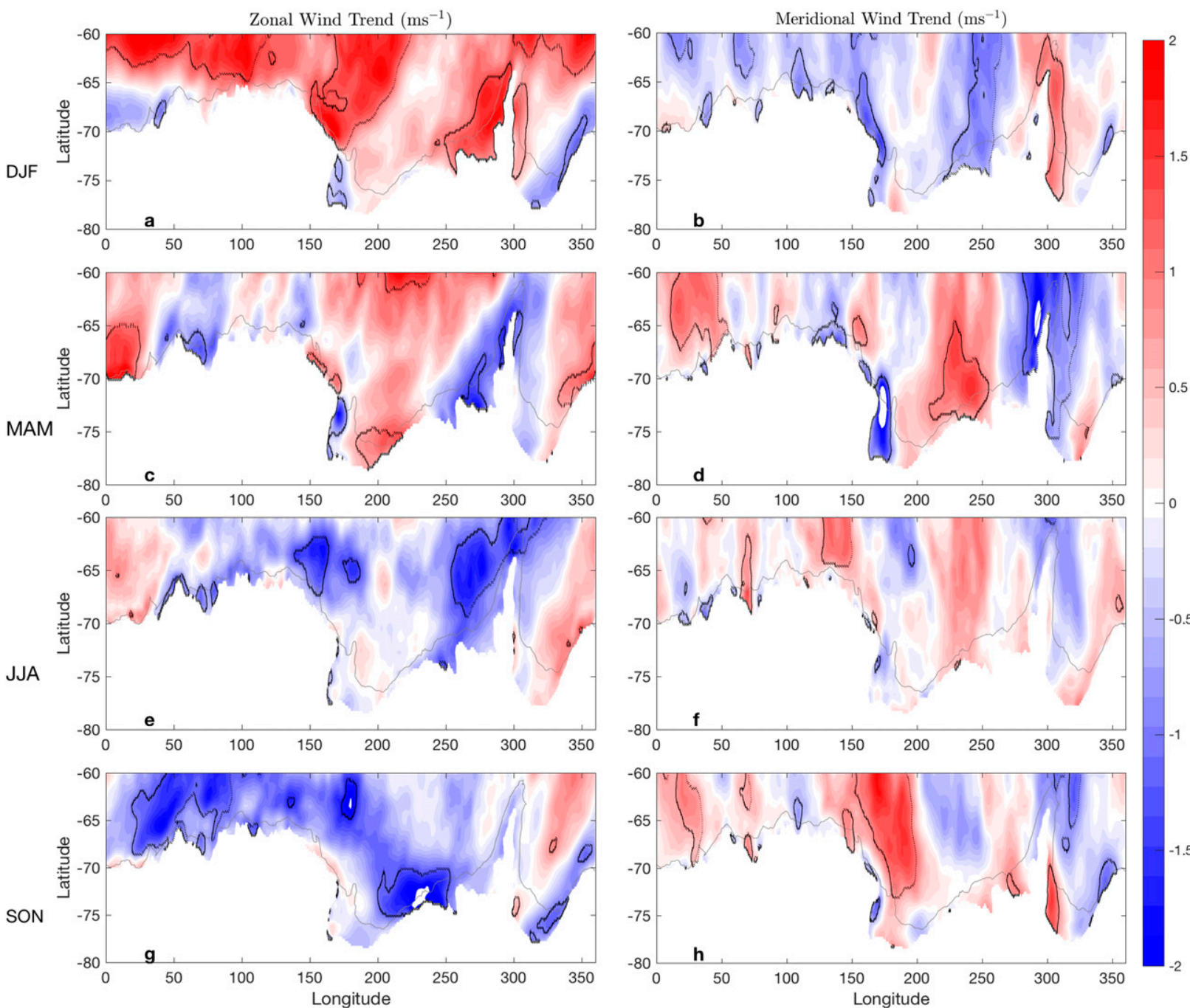

FIG. A1. Multidecadal trends in the seasonal-mean zonal and meridional 10-m winds (in m s ${ }^{-1}$ ), calculated from 1979-2015 ERAInterim data (Dee et al. 2011). Black contours envelop trends that are statistically significant at the $10 \%$ level. (a) DJF zonal wind trend, (b) DJF meridional wind trend, (c) MAM zonal wind trend, (d) MAM meridional wind trend, (e) JJA zonal wind trend, (f) JJA meridional wind trend, (g) SON zonal wind trend, and (h) SON meridional wind trend.

produced during autumn and winter when there are generally weaker winds. The amplification of the seasonal trends in the wind stress may therefore act to enhance the seasonal variations in AABW properties.

Seasonal changes in wind forcing may also project onto oceanic heat transport toward the continent. The trend toward weaker austral summer and spring easterly wind stress adjacent to the Amundsen and Bellingshausen Seas (see Figs. 4f,j), where the ACC lies closest to the continent, may be enhancing the shoreward flux of CDW (Thoma et al. 2008), and contributing to the ongoing warming of these west Antarctic continental shelves (Schmidtko et al. 2014). Figure 4j shows this substantial $\left(\sim 0.05 \mathrm{~N} \mathrm{~m}^{-2}\right)$ weakening of the easterlies in austral spring. The ice shelf thinning seen in West Antarctica (Rignot et al. 2013) may be tied to the trends apparent in the wind stress.

Offshore of the Fimbul Ice Shelf, two wind-influenced mechanisms of shoreward heat transport have been identified that are tied to the easterly wind stress: Ekman transport of relatively warm summer surface water (Zhou et al. 2014) and deep intrusion of CDW (Nøst et al. 2011; Hattermann et al. 2014). Our calculated wind stress trends that show a reduction of the strength of the easterlies in austral summer will limit the available warm water at the ice shelf front during the summer, thus reducing melt. However, the same trend in the easterlies will enhance the intrusion of $\mathrm{CDW}$, with more $\mathrm{CDW}$ intrusion expected in 

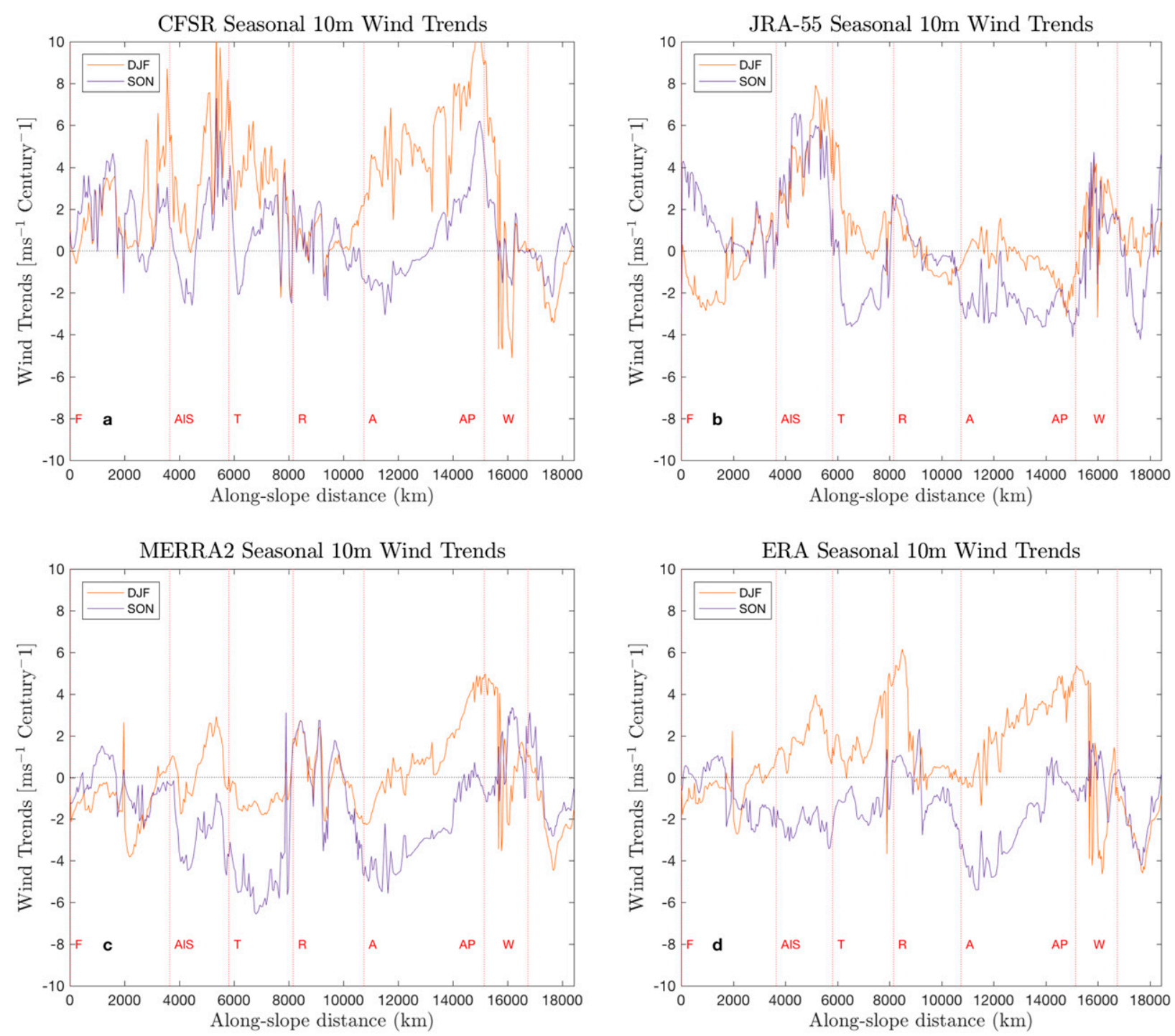

FIG. A2. The multidecadal trend in the DJF and SON along-slope 10-m winds (in m s ${ }^{-1}$ ), calculated from 1979-2015 MERRA2 (Gelaro et al. 2017) data, 1980-2010 CFSR Saha et al. (2010) data, 1973-2012 JRA-55 (Kobayashi et al. 2015) data, and 1979-2014 ERA-Interim (Dee et al. 2011) data.

summer and autumn (Spence et al. 2014). Antarctica's floating ice shelves may therefore be expected, on average, to exhibit reduced melt adjacent to the ice shelf face and enhanced melting close to their grounding lines, though with substantial variations associated with the spatially inhomogeneous wind stress trends.

\section{Conclusions}

In this article, we quantified the multidecadal change in the easterly surface wind forcing around Antarctica using ERA-Interim data and compared our findings with three other reanalysis products that compare favorably with Antarctic meteorological measurements (Bracegirdle
2013; Bromwich et al. 2011). The emphasis in this study is on the alongshore component of the surface forcing, as this component is most relevant for cross-slope exchange of water masses (e.g., Thompson et al. 2014). We find that, despite the increase in SAM in recent decades, the easterlies have on average strengthened by $0.0044 \mathrm{~N} \mathrm{~m}^{-2}$, or by around $7 \%$, though this trend is not statistically significant. This corresponds to an anomalous shoreward Ekman transport of around $0.6 \mathrm{~Sv}\left(1 \mathrm{~Sv} \equiv 10^{6} \mathrm{~m}^{3} \mathrm{~s}^{-1}\right)$ around the $\sim 18000 \mathrm{~km}$ length of the Antarctic shelf break. The annual-mean wind stress trend differs substantially between reanalysis products, but an aggregation of these products similarly indicates little overall change in the annual-mean wind stress (see Table 4). 

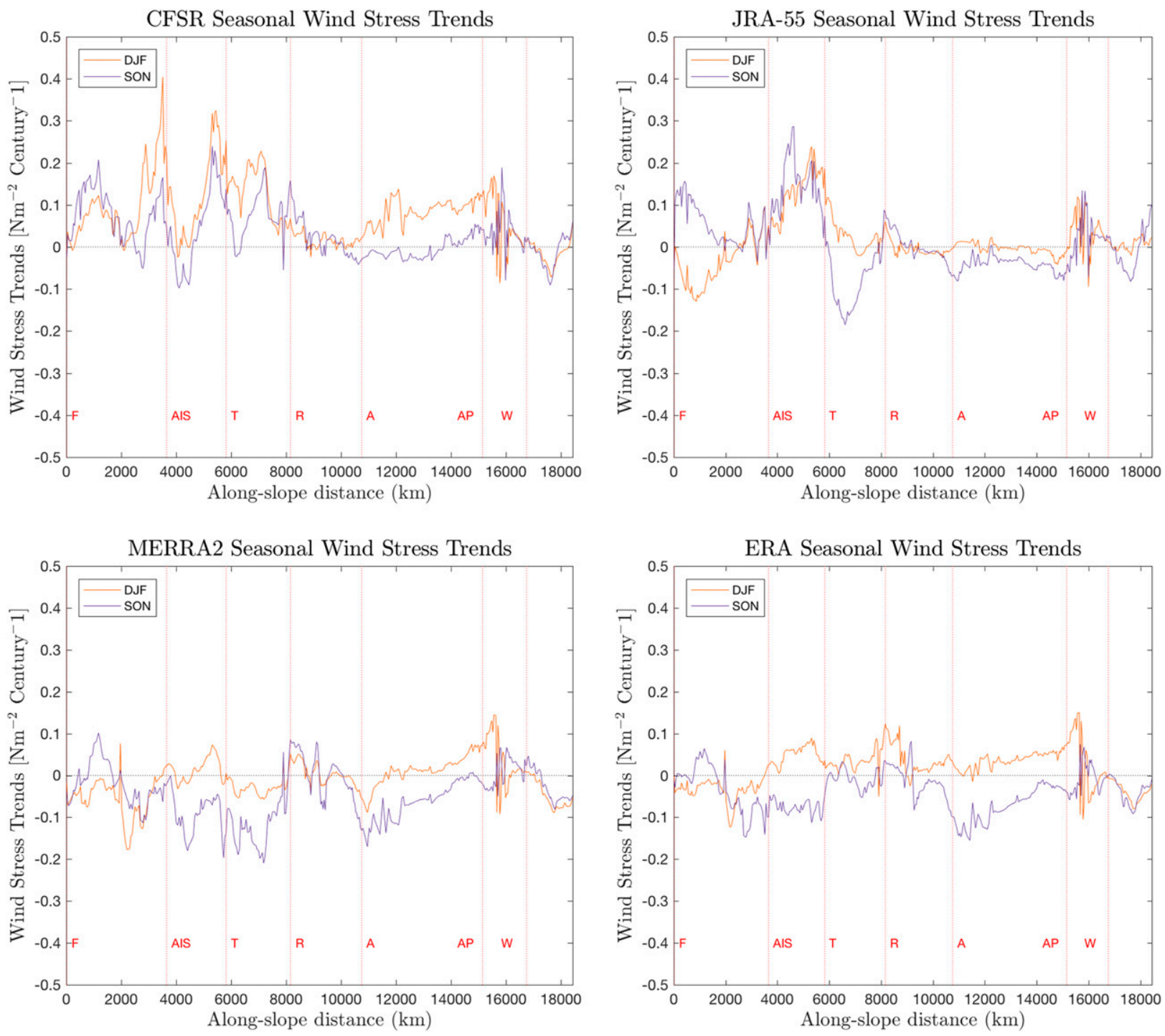

FIG. A3. The multidecadal trend in the DJF and SON along-slope wind stress (in $\mathrm{N} \mathrm{m}^{-2}$ century ${ }^{-1}$ ) calculated from the respective 10-m wind speeds for 1979-2015 MERRA2 (Gelaro et al. 2017) data, 1980-2010 CFSR (Saha et al. 2010) data, 1973-2012 JRA-55 (Kobayashi et al. 2015) data, and 1979-2014 ERA-Interim (Dee et al. 2011) data.

In contrast, ERA-Interim wind stress exhibits substantial seasonal trends, in particular a widening of the gap between the weaker summer easterlies and the stronger winter easterlies (see Table 3). In DJF and MAM, this amounts to the easterly wind stress trend weakening by $0.0055(12 \%)$ and $0.0022 \mathrm{~N} \mathrm{~m}^{-2}$ (3\%), equivalent to offshore Ekman transport anomalies of approximately 0.7 and $0.3 \mathrm{~Sv}$, respectively. In JJA and SON, the easterlies have strengthened by 0.112 $(15 \%)$ and $0.0143 \mathrm{~N} \mathrm{~m}^{-2}(22 \%)$, equivalent to shoreward Ekman transport anomalies of 1.5 and $1.9 \mathrm{~Sv}$, respectively. There are substantial regional departures from these circumpolar-average trends, as shown in Figs. 3 and 4, with seasonal trends reaching $0.05 \mathrm{~N} \mathrm{~m}^{-2}$ along various stretches of the shelf break. Despite widely varying annual-mean trends, all reanalysis products examined here exhibit a qualitatively similar widening of the gap between the SON and DJF easterly wind stresses (see Figs. 6, 7).

In section $3 \mathrm{c}$, we investigated the extent to which the wind stress trends can be attributed to the trends in the SAM, quantified via $\Delta P_{\text {SAM }}$, and to the pole-to-coast pressure gradient $\Delta P_{\text {Kat }}$ that drives the katabatic winds. On interannual time scales, the easterly wind stress is correlated with both $\Delta P_{\mathrm{Kat}}$ and $\Delta P_{\mathrm{SAM}}$, with the former explaining more of the variance than the latter $(\sim 50 \%$ vs $\sim 25 \%$ ) in both DJF and SON. The seasonal trends show a decrease in the strength of the easterlies 


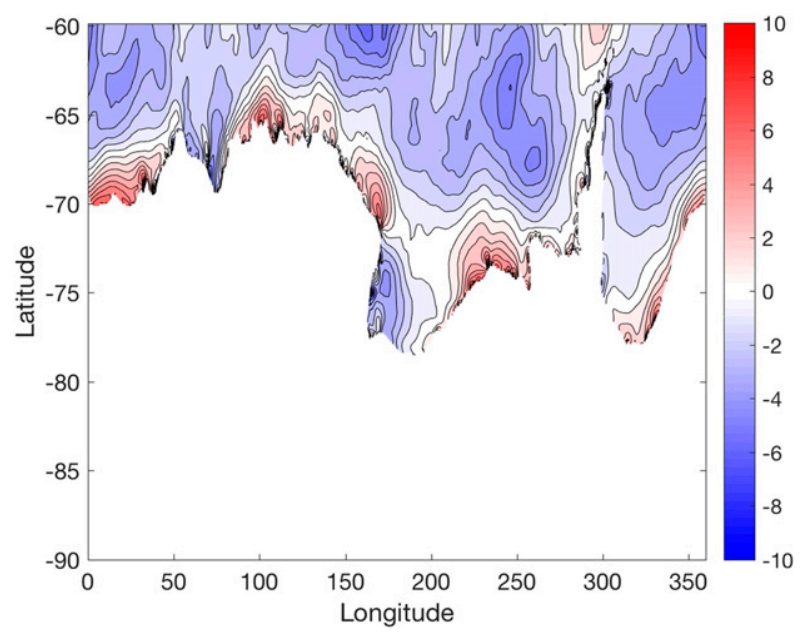

FIG. A4. The difference in the 2006-14 averaged 10-m zonal wind between ERA-Interim (Dee et al. 2011) and AMPS (Powers et al. 2003, 2012). AMPS data has been provided by the Byrd Polar Research Center's Polar Meteorology Group at The Ohio State University. Land points have been removed to highlight the ocean regions relevant to this study.

accompanied vby an increase in $\Delta P_{\mathrm{SAM}}$ in DJF. In SON, the trends reveal an increase in the strength of the easterly wind stress accompanied by an increase in $\Delta P_{\text {Kat }}$. This suggests a summer weakening of the easterlies because of the southward shift of the westerlies and spring intensification of the easterlies because of a stronger driving of the katabatic winds. However, while these were unambiguously the strongest pressure gradient and wind stress trends in ERAInterim, only the summer SAM trend and winter strengthening of the easterlies were statistically significant at the $10 \%$ level. Further scrutiny of these relationships will therefore be required in order to establish their robustness.

Throughout this study, we have examined the surface wind stress, rather than the wind speed. We made this choice because it is the momentum transfer from the atmosphere to the ocean that is most relevant to the near-Antarctic circulation, as outlined in sections 1 and 4. However, we are unable to distinguish directly if changes in the sea ice cover, which changes the surface roughness (Lüpkes and Birnbaum 2005), might be contributing to the trends. In the appendix, we show that the trends in the ERA-Interim 10-m wind speed are qualitatively similar to the trends in the wind stress. The alongshore wind speed exhibits increases in seasonality that are qualitatively similar to the wind stress trends in all reanalysis products. Furthermore, in the appendix, we construct an independent approximation of the alongshore wind stress trends, derived from the wind speeds via a simple quadratic bulk formula, and find quantitatively similar trends as reported by the model. We therefore infer that the trends in the wind stress are primarily a result of changes in the winds, rather than changes in sea ice conditions. However, sea ice can efficiently redistribute momentum laterally, and further work will be required to determine how changes in sea ice properties are contributing to the trends in the momentum input to the ocean (Leppäranta 2011).

Another caveat to this analysis is that reanalysis products are relatively poorly constrained close to Antarctica because of sparse measurements (see Saha et al. 2010; Dee et al. 2011; Kobayashi et al. 2015; Gelaro et al. 2017). This motivated a comparison of our results across four different products that have been evaluated using Antarctic meteorological measurements, with ERAInterim exhibiting substantially smaller decadal-mean biases in MSLP and geopotential height than the other three (Bracegirdle and Marshall 2012). In turn, ERAInterim's low MSLP biases motivated our attribution of the diagnosed wind stress trends to annular meridional pressure gradients, specifically $\Delta P_{\mathrm{SAM}}$ and $\Delta P_{\text {Kat }}$, the latter being defined as an analog of the SAM. Changes in the strength of the westerly wind belt and intensification of the katabatic winds could be more directly quantified and may offer a less ambiguous attribution of the wind stress trends. In section 3, we compared these reanalysis products over their full respective time spans, which may be expected to introduce slight differences between the trends derived from different products. In the appendix, we recalculate the trends over a uniform period (1980-2010) and find qualitatively similar results, though the ERAInterim and MERRA2 easterly wind strengthening in SON is no longer statistically significant over this shorter analysis period.

In section 4, we discussed qualitatively how the calculated trends may impact specific aspects of the regional Antarctic circulation. Given the wide range of Antarctic ocean processes that are tied to the easterly winds, there may be a specific connection between these wind stress trends, the observed multidecadal changes in water mass properties around the Antarctic margins (Schmidtko et al. 2014), and the ongoing warming and freshening of AABW (Purkey and Johnson 2010). Further work is necessary to quantify the ocean's response to multidecadal changes in the easterly wind belt.

Acknowledgments. This material is based in part upon work supported by the National Science Foundation under Grants OCE-1538702 and PLR-1543388. The authors thank ECMWF, NCAR, and NASA GES DISC for access to the available ERA-Interim, CFSR, 

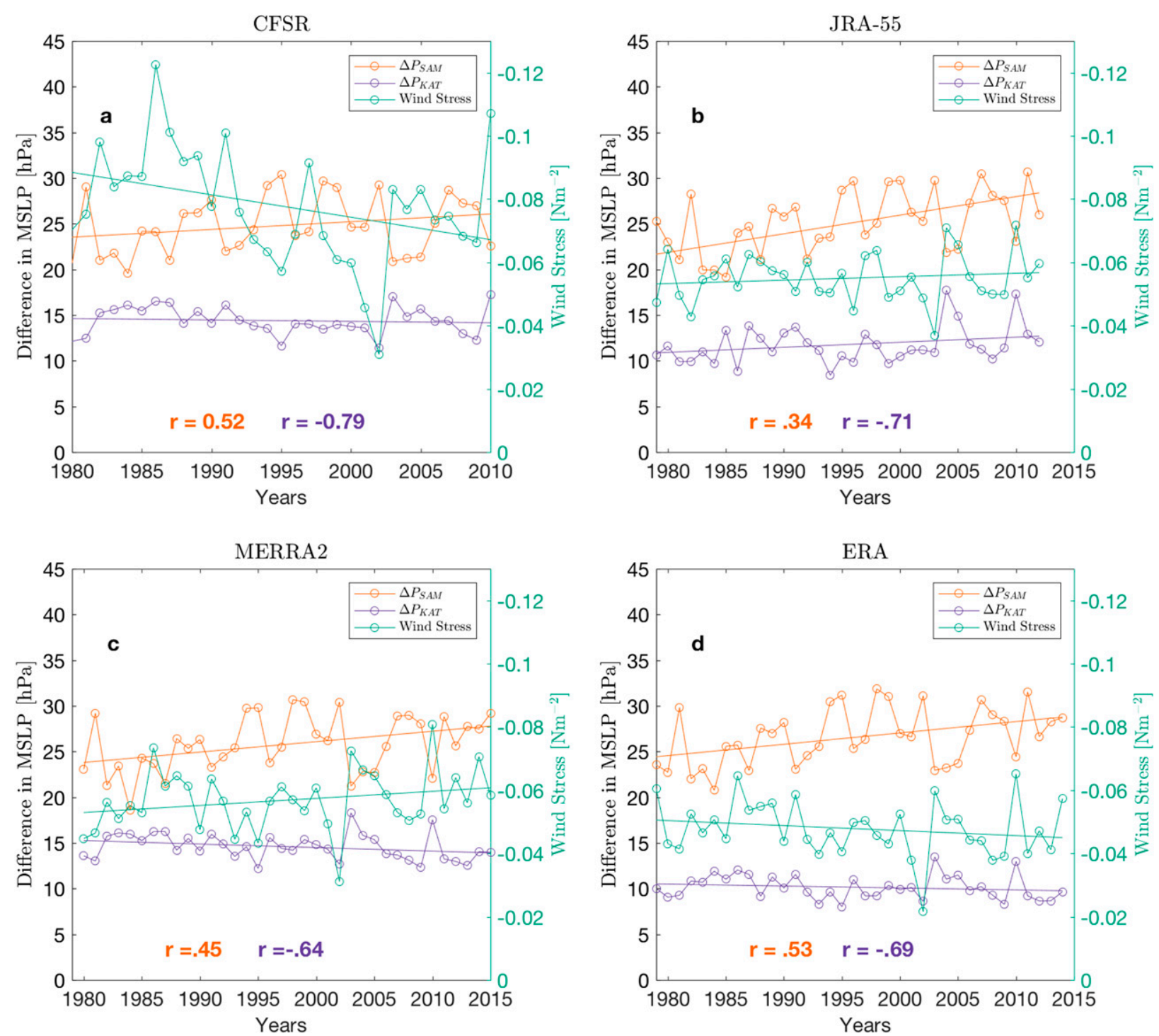

FIG. A5. As in Fig. 8, but calculating the DJF $\Delta P_{\text {Kat }}$ using the hypsometric equation in order to calculate the MSLP at $85^{\circ}$ and $65^{\circ}$ S from reanalysis surface pressure, 2-m temperature, and geopotential height.

MERRA2, and JRA-55 datasets. The authors thank Andrew Thompson for his constructive comments that improved this paper.

\section{APPENDIX}

\section{a. Analysis of the seasonal wind trends}

We focus on the seasonal easterly wind stress trends, rather than the wind speed trends, because the wind stress more directly impacts the ocean circulation. For comparison, we now repeat our seasonal trend analysis for the wind speed. We first provide in Fig. A1 seasonal plots of the zonal and meridional 10-m winds in ERA-Interim. For comparison, we also calculate the 10-m wind trends from 1980-2010 CFSR (Saha et al. 2010), 1979-2015 MERRA2 (Gelaro et al. 2017), 1973-2012 JRA-55 (Kobayashi et al. 2015), and 1979-2014 ERA-Interim (Dee et al. 2011). Figure A2 shows the SON and DJF alongshore wind trends diagnosed from all four reanalysis products. These figures indicate that the wind stress trends are primarily due to changes in the winds, rather than, for example, changes in surface roughness associated with sea ice.

To quantify the influence of the wind speed trends on the wind stress trends, we performed an independent estimate of the wind stress trends using a simple quadratic drag law, 

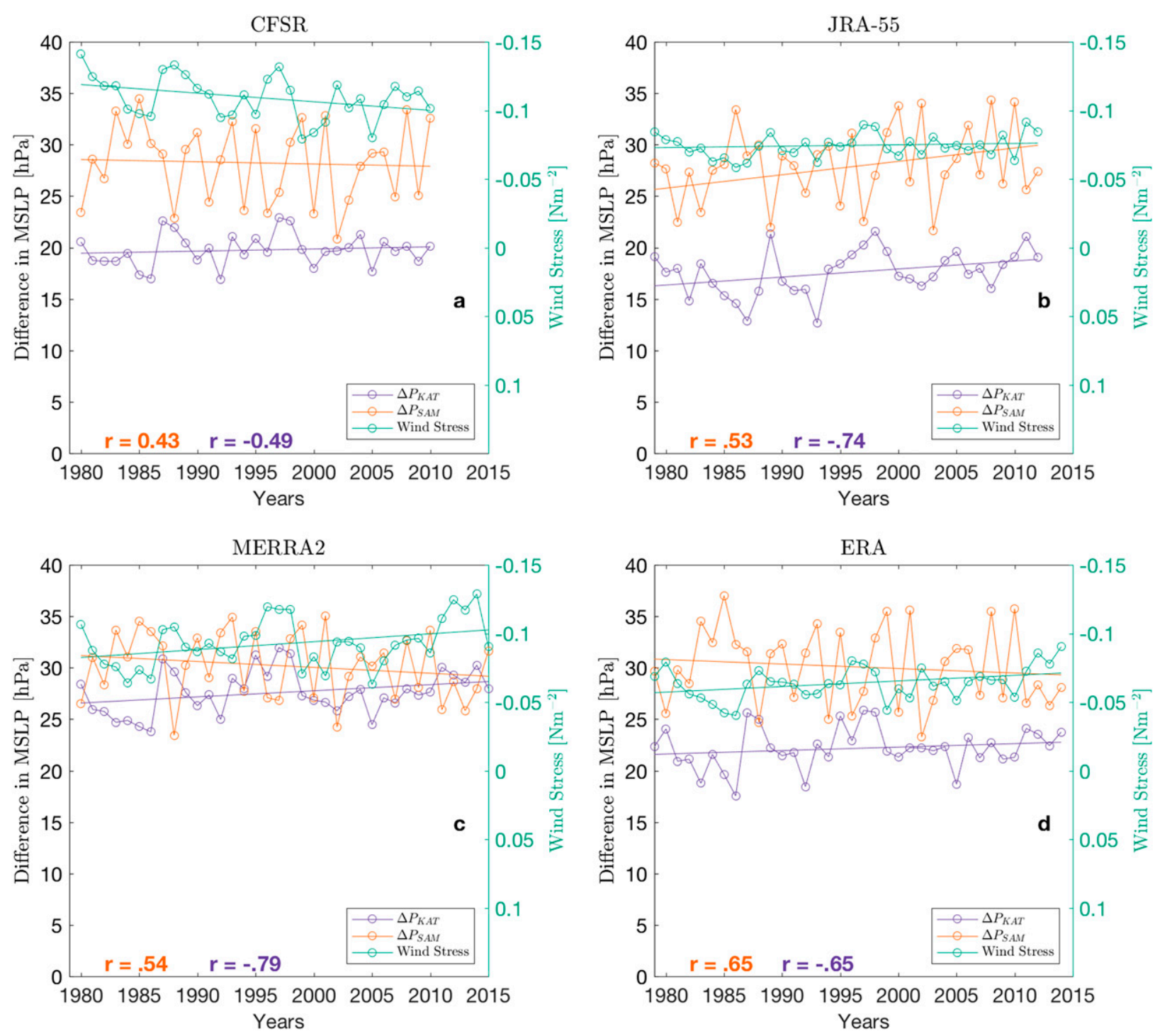

FIG. A6. As in Fig. 9, but calculating the SON $\Delta P_{\text {Kat }}$ using the hypsometric equation in order to calculate the MSLP at $85^{\circ}$ and $65^{\circ} \mathrm{S}$ from reanalysis surface pressure, 2-m temperature, and geopotential height.

$$
\tau=\rho C_{d} \mathbf{u}_{10} \mathbf{u}_{10} .
$$

Here, $\rho=1.023 \mathrm{~kg} \mathrm{~m}^{-3}$ is a constant reference density of dry air, $C_{d}=2 \times 10^{-3}$ is a typical bulk drag coefficient for sea ice (Lüpkes and Birnbaum 2005), and $\mathbf{u}_{10}$ is the $10-\mathrm{m}$ wind velocity vector. In Fig. A3, we reproduce Fig. 6, but using the stress derived via the above drag law. The DJF and SON alongshore wind stress trends are both qualitatively and quantitatively similar between the two figures, indicating that the

TABLE A1. The $P$ values of the interannual correlations between $\Delta P_{\mathrm{SAM}}, \Delta P_{\mathrm{Kat}}$, and the wind stress. Values in bold are significant at $10 \%$.

\begin{tabular}{lcccc}
\hline \hline \multicolumn{1}{c}{ Product } & DJF $\Delta P_{\text {SAM }}$ & SON $\Delta P_{\text {SAM }}$ & DJF $\Delta P_{\text {Kat }}$ & SON $\Delta P_{\text {Kat }}$ \\
\hline ERA-Interim & $\mathbf{1} \times \mathbf{1 0}^{-3}$ & $\mathbf{2} \times \mathbf{1 0}^{-5}$ & $\mathbf{3} \times \mathbf{1 0}^{-\mathbf{6}}$ & $\mathbf{3} \times \mathbf{1 0}^{-\mathbf{7}}$ \\
CFSR & $\mathbf{3} \times \mathbf{1 0}^{-\mathbf{3}}$ & 0.40 & $\mathbf{2} \times \mathbf{1 0}^{-\mathbf{7}}$ & $\mathbf{0 . 0 1}$ \\
JRA-55 & $\mathbf{3} \times \mathbf{1 0}^{-\mathbf{2}}$ & $\mathbf{5} \times \mathbf{1 0}^{-\mathbf{4}}$ & $\mathbf{8} \times \mathbf{1 0}^{-\mathbf{7}}$ & $\mathbf{5} \times \mathbf{1 0}^{-\mathbf{5}}$ \\
MERRA2 & $\mathbf{6} \times \mathbf{1 0}^{-\mathbf{3}}$ & $\mathbf{6} \times \mathbf{1 0}^{-\mathbf{4}}$ & $\mathbf{2} \mathbf{1 0}^{-\mathbf{3}}$ & $\mathbf{3} \times \mathbf{1 0}^{-\mathbf{6}}$ \\
\hline
\end{tabular}


TABLE A2. Trends in the circumpolar-averaged alongshore wind stress and meridional pressure gradients with the corresponding statistical $p$ values in the superscript of each trend for years 1980-2010; $p$ values in bold are significant at $10 \%$.

\begin{tabular}{|c|c|c|c|c|}
\hline Variable & ERA-Interim & MERRA2 & CFSR & JRA-55 \\
\hline $\begin{array}{l}\text { Mean annual wind stress trend }\left(\mathrm{N} \mathrm{m}^{-2}\right. \\
\left.\text { century }^{-1}\right)\end{array}$ & $-0.005^{0.80}$ & $-0.029^{0.15}$ & $0.058^{\mathbf{0 . 0 0 6}}$ & $-0.007^{0.48}$ \\
\hline DJF wind stress trend $\left(\mathrm{N} \mathrm{m}^{-2}\right.$ century $\left.{ }^{-1}\right)$ & $0.013^{0.45}$ & $-0.020^{0.31}$ & $0.069^{\mathbf{0 . 0 6}}$ & $-0.003^{0.86}$ \\
\hline DJF $\Delta P_{\text {SAM }}\left(\mathrm{hPa}\right.$ century $\left.^{-1}\right)$ & $14.01^{\mathbf{0 . 0 2}}$ & $10.2^{\mathbf{0 . 1 0}}$ & $8.20^{0.20}$ & $16.6^{\mathbf{0 . 0 1}}$ \\
\hline DJF $\Delta P_{\text {Kat }}\left(\mathrm{hPa} \mathrm{century}^{-1}\right)$ & $-0.320^{0.96}$ & $-2.75^{0.29}$ & $-1.48^{0.66}$ & $2.22^{\mathbf{0 . 0 0 4}}$ \\
\hline SON wind stress trend $\left(\mathrm{N} \mathrm{m}^{-2}\right.$ century $\left.{ }^{-1}\right)$ & $-0.015^{0.44}$ & $-0.012^{0.69}$ & $0.061^{\mathbf{0 . 0 4}}$ & $-0.012^{0.42}$ \\
\hline SON $\Delta P_{\text {SAM }}\left(\mathrm{hPa}\right.$ century $\left.{ }^{-1}\right)$ trend & $-2.27^{0.76}$ & $-1.44^{0.82}$ & $-2.10^{0.78}$ & $12.1^{\mathbf{0 . 0 9}}$ \\
\hline SON $\Delta P_{\text {Kat }}\left(\right.$ hPa century $\left.{ }^{-1}\right)$ trend & $1.50^{0.68}$ & $7.20^{\mathbf{0 . 0 6}}$ & $1.85^{0.54}$ & $6.07^{\mathbf{0 . 0 3}}$ \\
\hline
\end{tabular}

reported wind stress trends are primarily due to changes in the wind speed.

\section{b. Comparison against the AMPS}

To evaluate the impact of reanalysis resolution on representation of the near-coastal winds, we compare the ERA-Interim winds against the output of the AMPS forecast (Hines et al. 2011; Powers et al. 2012) over the period that AMPS data are available (2006-15). Figure A4 shows the difference between the mean 10-m winds in ERAInterim and AMPS. For this comparison, the AMPS wind velocity data were rotated and interpolated onto the same regular latitude-longitude grid as ERAInterim. A key difference is that the coastal winds in ERA-Interim are consistently slower than in AMPS, likely because of the higher resolution used in the latter. The AMPS midlatitude westerly winds are also stronger than in ERA-Interim. The differences in the mean wind are of comparable magnitude to the diagnosed multidecadal trends in ERA-Interim.

\section{c. Calculation of katabatic index from surface pressure}

The calculation of $\Delta P_{\text {Kat }}$ relies on the MSLP at $65^{\circ}$ and $85^{\circ} \mathrm{S}$, and the South Pole at $85^{\circ} \mathrm{S}$ lies at a high elevation of $2700 \mathrm{~m}$. To investigate whether the results of $\Delta P_{\text {Kat }}$ are biased by the methods that reanalysis products use reduce the surface pressure to MSLP, we calculate an independent estimate of the MSLP from the reported surface pressures in all products. We use the hypsometric equation to find the seasonal zonal MSLP at $85^{\circ}$ and $65^{\circ} \mathrm{S}$ as follows:

$$
\operatorname{MSLP}=P_{\text {surf }} \exp \frac{Z g_{0}}{R_{d} T_{v}}
$$

Here, $P_{\text {surf }}$ is the reanalysis-reported surface pressure, $R_{d}$ is the universal gas constant, $g_{0}$ is gravity, $Z$ is the height above sea level, and $T_{v}$ is virtual temperature. In Figs. A5 and A6 we reproduce Figs. 8 and 9 using our independent estimate of $\Delta P_{\text {Kat }}$. The time-mean values of $\Delta P_{\text {Kat }}$ shown in Figs. A5 and A6 differ from those shown in Figs. 8 and 9, typically by around $10 \mathrm{hPa}$, because of our relatively simplistic method of estimating MSLP. However, the interannual correlations and multidecadal trends in $\Delta P_{\text {Kat }}$ are very similar. We therefore conclude that reanalysis-specific procedures for estimating MSLP do not influence our main results.

\section{d. Calculation of the interannual trends using a consistent 1980-2010 time period}

In section 3, we reported trends calculated over the full time span of each reanalysis product, which differ slightly from one another. We show the $p$ values of the interannual correlations between the wind stress, $P_{\text {Kat }}$, and $P_{\text {Sam }}$ in Table A1. In Table A2, we present a recalculation of the trends and $p$ values reported in Table 4 but use a uniform time period of 1980-2010 across all reanalysis products. There is little change in the JRA-55 and CFSR trends because their analysis periods differ little between Tables 4 and A2. In ERA-Interim and MERRA2, there are some more substantial changes. For example, while these products still report a strengthening of the easterly wind stress in SON over 1980-2010, these trends are no longer statistically significant.

\section{REFERENCES}

Amante, C., and B. W. Eakins, 2009: ETOPO1 1 Arc-Minute Global Relief Model: Procedures, data sources and analysis. NOAA Tech. Memo. NESDIS NGDC-24, 9 pp.

Amblas, D., and J. A. Dowdeswell, 2018: Physiographic influences on dense shelf-water cascading down the Antarctic continental slope. Earth-Sci. Rev., 185, 887-900, https://doi.org/10.1016/ j.earscirev.2018.07.014.

Bracegirdle, T. J., 2013: Climatology and recent increase of westerly winds over the Amundsen Sea derived from six reanalyses. Int. J. Climatol., 33, 843-851, https://doi.org/10.1002/ joc.3473.

_ - and G. J. Marshall, 2012: The reliability of Antarctic tropospheric pressure and temperature in the latest global reanalyses. J. Climate, 25, 7138-7146, https://doi.org/10.1175/JCLI-D-11-00685.1.

Bromwich, D. H., and R. L. Fogt, 2004: Strong trends in the skill of the ERA-40 and NCEP-NCAR reanalyses in the high and midlatitudes of the Southern Hemisphere, 1958-2001. J. Climate, 17, 4603-4619, https://doi.org/10.1175/3241.1. 
__ J. P. Nicolas, and A. J. Monaghan, 2011: An assessment of precipitation changes over Antarctica and the Southern Ocean since 1989 in contemporary global reanalyses. J. Climate, 24, 4189-4209, https://doi.org/10.1175/2011JCLI4074.1.

Clem, K. R., J. A. Renwick, J. McGregor, and R. L. Fogt, 2016: The relative influence of ENSO and SAM on Antarctic Peninsula climate. J. Geophys. Res. Atmos., 121, 9324-9341, https://doi.org/ 10.1002/2016JD025305.

Dee, D. P., and Coauthors, 2011: The ERA-Interim reanalysis: Configuration and performance of the data assimilation system. Quart. J. Roy. Meteor. Soc., 137, 553-597, https://doi.org/ 10.1002/qj.828.

Flexas, M. M., M. P. Schodlok, L. Padman, D. Menemenlis, and A. H. Orsi, 2015: Role of tides on the formation of the Antarctic Slope Front at the Weddell-Scotia Confluence. J. Geophys. Res. Oceans, 120, 3658-3680, https://doi.org/10.1002/2014JC010372.

Gelaro, R., and Coauthors, 2017: The Modern-Era Retrospective Analysis for Research and Applications, version 2 (MERRA-2). J. Climate, 30, 5419-5454, https://doi.org/10.1175/ JCLI-D-16-0758.1.

Gill, A. E., 1973: Circulation and bottom water production in the Weddell Sea. Deep-Sea Res. Oceanogr. Abstr., 20,111140, https://doi.org/10.1016/0011-7471(73)90048-X.

Gnanadesikan, A., and R. W. Hallberg, 2000: On the relationship of the Circumpolar Current to Southern Hemisphere winds in coarse-resolution ocean models. J. Phys. Oceanogr., 30, 2013-2034, https://doi.org/10.1175/1520-0485(2000)030<2013: OTROTC $>2.0 . \mathrm{CO} ; 2$.

Gordon, A. L., 1981: Seasonality of Southern Ocean sea ice. J. Geophys. Res., 86, 4193-4197, https://doi.org/10.1029/ JC086iC05p04193.

- B. Huber, D. McKee, and M. Visbeck, 2010: A seasonal cycle in the export of bottom water from the Weddell Sea. Nat. Geosci., 3, 551-556, https://doi.org/10.1038/ngeo916.

,-- , and J. Busecke, 2015: Bottom water export from the western Ross Sea, 2007 through 2010. Geophys. Res. Lett., 42, 5387-5394, https://doi.org/10.1002/2015GL064457.

Hattermann, T., L. H. Smedsrud, O. A. Nøst, J. M. Lilly, and B. K. Galton-Fenzi, 2014: Eddy-resolving simulations of the Fimbul Ice Shelf cavity circulation: Basal melting and exchange with the open ocean. Ocean Modell., 82, 28-44, https://doi.org/ 10.1016/j.ocemod.2014.07.004.

Haumann, F. A., N. Gruber, M. Münnich, I. Frenger, and S. Kern, 2016: Sea-ice transport driving Southern Ocean salinity and its recent trends. Nature, 537, 89-92, https://doi.org/10.1038/ nature19101.

Heywood, K. J., and Coauthors, 2016: Between the devil and the deep blue sea: The role of the Amundsen Sea continental shelf in exchanges between ocean and ice shelves. Oceanography, 29 (4), 118-129, https://doi.org/10.5670/oceanog.2016.104.

Hines, K. M., D. H. Bromwich, L.-S. Bai, M. Barlage, and A. G. Slater, 2011: Development and testing of polar WRF. Part III: Arctic land. J. Climate, 24, 26-48, https://doi.org/10.1175/ 2010JCLI3460.1.

Hogg, A. M., M. P. Meredith, D. P. Chambers, E. P. Abrahamsen, C. W. Hughes, and A. K. Morrison, 2015: Recent trends in the Southern Ocean eddy field. J. Geophys. Res. Oceans, 120, 257-267, https://doi.org/10.1002/2014JC010470.

Holland, P. R., and R. Kwok, 2012: Wind-driven trends in Antarctic sea-ice drift. Nat. Geosci., 5, 872-875, https://doi.org/10.1038/ ngeo1627.

Hughes, C. W., M. P. Meredith, and K. J. Heywood, 1999: Winddriven transport fluctuations through the Drake Passage: A southern mode. J. Phys. Oceanogr., 29, 1971-1992, https://doi.org/ 10.1175/1520-0485(1999)029<1971:WDTFTD>2.0.CO;2.

Jacobs, S. S., 1991: On the nature and significance of the Antarctic Slope Front. Mar. Chem., 35, 9-24, https://doi.org/10.1016/ S0304-4203(09)90005-6.

Jenkins, A., P. Dutrieux, S. Jacobs, E. J. Steig, G. H. Gudmundsson, J. Smith, and K. J. Heywood, 2016: Decadal ocean forcing and Antarctic ice sheet response: Lessons from the Amundsen Sea. Oceanography, 29 (4), 106-117, https://doi.org/10.5670/ oceanog.2016.103.

Jullion, L., S. C. Jones, A. C. N. Garabato, and M. P. Meredith, 2010: Wind-controlled export of Antarctic Bottom Water from the Weddell Sea. Geophys. Res. Lett., 37, L09609, https:/ doi.org/10.1029/2010GL042822.

_ A. C. N. Garabato, M. P. Meredith, P. R. Holland, P. Courtois, and B. A. King, 2013: Decadal freshening of the Antarctic Bottom Water exported from the Weddell Sea. J. Climate, 26, 8111-8125, https://doi.org/10.1175/JCLI-D-12-00765.1.

Kida, S., 2011: The impact of open oceanic processes on the Antarctic Bottom Water outflows. J. Phys. Oceanogr., 41, 1941-1957, https://doi.org/10.1175/2011JPO4571.1.

Kobayashi, S., and Coauthors, 2015: The JRA-55 reanalysis: General specifications and basic characteristics. J. Meteor. Soc. Japan, 93, 5-48, https://doi.org/10.2151/jmsj.2015-001.

Kodama, Y., and G. Wendler, 1986: Wind and temperature regime along the slope of Adélie Land, Antarctica. J. Geophys. Res., 91, 6735-6741, https://doi.org/10.1029/JD091iD06p06735.

Kwok, R., S. S. Pang, and S. Kacimi, 2017: Sea ice drift in the Southern Ocean: Regional patterns, variability, and trends. Elem. Sci. Anthropocene, 5, 32, http://doi.org/10.1525/ elementa.226.

Langlais, C. E., S. R. Rintoul, and J. D. Zika, 2015: Sensitivity of Antarctic Circumpolar Current transport and eddy activity to wind patterns in the Southern Ocean. J. Phys. Oceanogr., 45 , 1051-1067, https://doi.org/10.1175/JPO-D-14-0053.1.

Lenton, A., and R. J. Matear, 2007: Role of the southern annular mode (SAM) in Southern Ocean $\mathrm{CO}_{2}$ uptake. Global Biogeochem. Cycles, 21, GB2016, https://doi.org/10.1029/ $2006 \mathrm{~GB} 002714$.

Leppäranta, M., 2011: The Drift of Sea Ice. Springer, 347 pp.

Lüpkes, C., and G. Birnbaum, 2005: Surface drag in the Arctic marginal sea-ice zone: A comparison of different parameterisation concepts. Bound.-Layer Meteor., 117, 179-211, https:// doi.org/10.1007/s10546-005-1445-8.

Marshall, G. J., 2003: Trends in the southern annular mode from observations and reanalyses. J. Climate, 16, 4134 4143, https://doi.org/10.1175/1520-0442(2003)016<4134: TITSAM $>2.0 . \mathrm{CO} ; 2$.

Marshall, J., and K. Speer, 2012: Closure of the meridional overturning circulation through Southern Ocean upwelling. Nat. Geosci., 5, 171-180, https://doi.org/10.1038/ngeo1391.

Mathiot, P., H. Goosse, T. Fichefet, B. Barnier, and H. Gallée, 2011: Modelling the seasonal variability of the Antarctic Slope Current. Ocean Sci., 7, 455-470, https://doi.org/10.5194/os-7455-2011.

McKee, D. C., X. Yuan, A. L. Gordon, B. A. Huber, and Z. Dong, 2011: Climate impact on interannual variability of Weddell Sea Bottom Water. J. Geophys. Res., 116, C05020, https:// doi.org/10.1029/2010JC006484.

Meehl, G. A., 1991: A reexamination of the mechanism of the semiannual oscillation in the Southern Hemisphere. J. Climate, 4, 911-926, https://doi.org/10.1175/1520-0442(1991)004<0911: AROTMO $>2.0 . \mathrm{CO} ; 2$. 
Meijers, A. J. S., M. P. Meredith, E. P. Abrahamsen, M. A. M. Maqueda, D. C. Jones, and A. C. N. Garabato, 2016: Winddriven export of Weddell Sea slope water. J. Geophys. Res. Oceans, 121, 7530-7546, https://doi.org/10.1002/2016JC011757.

Meredith, M. P., and A. M. Hogg, 2006: Circumpolar response of Southern Ocean eddy activity to a change in the southern annular mode. Geophys. Res. Lett., 33, L16608, https://doi.org/ 10.1029/2006GL026499.

- A. C. N. Garabato, A. L. Gordon, and G. C. Johnson, 2008: Evolution of the deep and bottom waters of the Scotia Sea, Southern Ocean, during 1995-2005. J. Climate, 21, 3327-3343, https://doi.org/10.1175/2007JCLI2238.1.

Munk, W. H., and E. Palmén, 1951: Note on the dynamics of the Antarctic Circumpolar Current. Tellus, 3, 53-55, https:// doi.org/10.3402/tellusa.v3i1.8609.

Nøst, O. A., M. Biuw, V. Tverberg, C. Lydersen, T. Hattermann, Q. Zhou, L. H. Smedsrud, and K. M. Kovacs, 2011: Eddy overturning of the Antarctic Slope Front controls glacial melting in the eastern Weddell Sea. J. Geophys. Res., 116, C11014, https://doi.org/10.1029/2011JC006965.

Parish, T. R., and K. T. Waight III, 1987: The forcing of Antarctic katabatic winds. Mon. Wea. Rev., 115, 2214-2226, https://doi.org/ 10.1175/1520-0493(1987)115<2214:TFOAKW >2.0.CO;2.

—_, and D. H. Bromwich, 1997: On the forcing of seasonal changes in surface pressure over Antarctica. J. Geophys. Res., 102, 13 785-13 792, https://doi.org/10.1029/96JD02959.

—, and - 2007: Reexamination of the near-surface airflow over the Antarctic continent and implications on atmospheric circulations at high southern latitudes. Mon. Wea. Rev., 135, 1961-1973, https://doi.org/10.1175/MWR3374.1.

_, P. Pettré, and G. Wendler, 1993: The influence of large-scale forcing on the katabatic wind regime at Adélie Land, Antarctica. Meteor. Atmos. Phys., 51, 165-176, https://doi.org/10.1007/ BF01030492.

Powers, J. G., A. J. Monaghan, A. M. Cayette, D. H. Bromwich, Y.-H. Kuo, and K. W. Manning, 2003: Real-time mesoscale modeling over Antarctica: The Antarctic Mesoscale Prediction System. Bull. Amer. Meteor. Soc., 84, 1533-1545, https://doi.org/ 10.1175/BAMS-84-11-1533.

- , K. W. Manning, D. H. Bromwich, J. J. Cassano, and A. M. Cayette, 2012: A decade of Antarctic science support through AMPS. Bull. Amer. Meteor. Soc., 93, 1699-1712, https:// doi.org/10.1175/BAMS-D-11-00186.1.

Purkey, S. G., and G. C. Johnson, 2010: Warming of global abyssal and deep Southern Ocean waters between the 1990s and 2000s: Contributions to global heat and sea level rise budgets. J. Climate, 23, 6336-6351, https://doi.org/10.1175/2010JCLI3682.1.

Renfrew, I. A., G. W. K. Moore, P. S. Guest, and K. Bumke, 2002: A comparison of surface layer and surface turbulent flux observations over the Labrador Sea with ECMWF analyses and NCEP reanalyses. J. Phys. Oceanogr., 32, 383-400, https://doi.org/ 10.1175/1520-0485(2002)032<0383:ACOSLA > 2.0.CO;2.

Rignot, E., S. Jacobs, J. Mouginot, and B. Scheuchl, 2013: Ice-shelf melting around Antarctica. Science, 341, 266-270, https://doi.org/ 10.1126/science.1235798.

Rintoul, S., 2010: Antarctic Circumpolar Current. Ocean Currents, 1st ed. J. Steele, S. Thorpe, and K. Turekian, Eds., Academic Press, 196-208.

Saha, S., and Coauthors, 2010: The NCEP Climate Forecast System Reanalysis. Bull. Amer. Meteor. Soc., 91, 1015-1057, https:// doi.org/10.1175/2010BAMS3001.1.

Sallée, J. B., K. G. Speer, and S. R. Rintoul, 2010: Zonally asymmetric response of the Southern Ocean mixed-layer depth to the southern annular mode. Nat. Geosci., 3, 273-279, https:// doi.org/10.1038/ngeo812.

Schmidtko, S., K. J. Heywood, A. F. Thompson, and S. Aoki, 2014: Multi-decadal warming of Antarctic waters. Science, 346, 12271231, https://doi.org/10.1126/science.1256117.

Shindell, D. T., and G. A. Schmidt, 2004: Southern Hemisphere climate response to ozone changes and greenhouse gas increases. Geophys. Res. Lett., 31, L18209, https://doi.org/10.1029/ 2004GL020724.

Simmonds, I., and D. A. Jones, 1998: The mean structure and temporal variability of the semiannual oscillation in the southern extratropics. Int. J. Climatol., 18, 473-504, https://doi.org/10.1002/ (SICI)1097-0088(199804)18:5<473::AID-JOC266>3.0.CO;2-0.

Smith, S. R., P. J. Hughes, and M. A. Bourassa, 2011: A comparison of nine monthly air-sea flux products. Int. J. Climatol., 31, 10021027, https://doi.org/10.1002/joc.2225.

Spence, P., S. M. Griffies, M. H. England, A. M. Hogg, O. A. Saenko, and N. C. Jourdain, 2014: Rapid subsurface warming and circulation changes of Antarctic coastal waters by poleward shifting winds. Geophys. Res. Lett., 41, 4601-4610, https:// doi.org/10.1002/2014GL060613.

Stark, J. D., C. J. Donlon, M. J. Martin, and M. E. McCulloch, 2007: OSTIA: An operational, high resolution, real time, global sea surface temperature analysis system. Oceans 2007-Europe, Aberdeen, Scotland, IEEE, 061214-029, http://ghrsst-pp.metoffice. com/pages/latest_analysis/docs/Stark_et_al_OSTIA_description_ Oceans07.pdf.

Stewart, A. L., and A. F. Thompson, 2012: Sensitivity of the ocean's deep overturning circulation to easterly Antarctic winds. Geophys. Res. Lett., 39, L18604, https://doi.org/10.1029/ 2012GL053099.

- and - 2013: Connecting Antarctic cross-slope exchange with Southern Ocean overturning. J. Phys. Oceanogr., 43, 1453-1471, https://doi.org/10.1175/JPO-D-12-0205.1.

, and _ 2015a: Eddy-mediated transport of warm Circumpolar Deep Water across the Antarctic Shelf Break. Geophys. Res. Lett., 42, 432-440, https://doi.org/10.1002/2014GL062281. , and,$- 2015 \mathrm{~b}$ : The neutral density temporal residual mean overturning circulation. Ocean Modell., 90, 44-56, https:// doi.org/10.1016/j.ocemod.2015.03.005.

, and - 2016: Eddy generation and jet formation via dense water outflows across the Antarctic continental slope. J. Phys. Oceanogr., 46, 3729-3750, https://doi.org/10.1175/ JPO-D-16-0145.1.

, A. Klocker, and D. Menemenlis, 2018: Circum-Antarctic shoreward heat transport derived from an eddy- and tideresolving simulation. Geophys. Res. Lett., 45, 834-845, https:// doi.org/10.1002/2017GL075677.

Su, Z., A. L. Stewart, and A. F. Thompson, 2014: An idealized model of Weddell Gyre export variability. J. Phys. Oceanogr., 44, 1671-1688, https://doi.org/10.1175/JPO-D-13-0263.1.

Swart, N. C., and J. C. Fyfe, 2012: Observed and simulated changes in the Southern Hemisphere surface westerly wind-stress. Geophys. Res. Lett., 39, L16711, https://doi.org/10.1029/ 2012 GL052810.

Thoma, M., A. Jenkins, D. Holland, and S. Jacobs, 2008: Modelling Circumpolar Deep Water intrusions on the Amundsen Sea Continental Shelf, Antarctica. Geophys. Res. Lett., 35, L18602, https://doi.org/10.1029/2008GL034939.

Thompson, A. F., K. J. Heywood, S. Schmidtko, and A. L. Stewart, 2014: Eddy transport as a key component of the Antarctic Overturning Circulation. Nat. Geosci., 7, 879-884, https://doi.org/ 10.1038/ngeo2289. 
Thompson, D. W. J., and S. Solomon, 2002: Interpretation of recent Southern Hemisphere climate change. Science, 296, 895-899, https://doi.org/10.1126/science.1069270.

Turner, J., and Coauthors, 2005: Antarctic climate change during the last 50 years. Int. J. Climatol., 25, 279-294, https://doi.org/ 10.1002/joc. 1130 .

—_, T. Phillips, J. S. Hosking, G. J. Marshall, and A. Orr, 2013: The Amundsen Sea low. Int. J. Climatol., 33, 1818-1829, https:// doi.org/10.1002/joc.3558.

Wang, G., W. Cai, and A. Purich, 2014: Trends in Southern Hemisphere wind-driven circulation in CMIP5 models over the 21st century: Ozone recovery versus greenhouse forcing. J. Geophys. Res. Oceans, 119, 2974-2986, https://doi.org/10.1002/ 2013JC009589.
Wang, Q., S. Danilov, E. Fahrbach, J. Schröter, and T. Jung, 2012: On the impact of wind forcing on the seasonal variability of Weddell Sea Bottom Water transport. Geophys. Res. Lett., 39, L06603, https://doi.org/10.1029/2012GL051198.

Zhou, Q., T. Hattermann, O. A. Nøst, M. Biuw, K. M. Kovacs, and C. Lydersen, 2014: Wind-driven spreading of fresh surface water beneath ice shelves in the eastern Weddell Sea. J. Geophys. Res. Oceans, 119, 3818-3833, https://doi.org/ 10.1002/2013JC009556.

Zika, J. D., J. Le Sommer, C. O. Dufour, A. Naveira-Garabato, and A. Blaker, 2013: Acceleration of the Antarctic Circumpolar Current by wind stress along the coast of Antarctica. J. Phys. Oceanogr., 43, 2772-2784, https://doi.org/10.1175/ JPO-D-13-091.1. 